\title{
Ecosystem Carbon Stocks of Restored Mangroves and Its Sequestration in Northern Sumatra Coast, Indonesia
}

\author{
Bambang Suprayogi $^{1{ }^{*}}$, J. Purbopuspito ${ }^{2}$, Meilinda Suriani Harefa ${ }^{3}$, G. Y. Panjaitan ${ }^{4}$, Z. Nasution ${ }^{5}$ \\ ${ }^{1}$ Faculty of Fishery and Marine Science, Brawijaya University, Malang, Indonesia \\ ${ }^{2}$ Department of Soil, Faculty of Agriculture, Sam Ratulangi University, Menado, Indonesia \\ ${ }^{3}$ Department of Geography, Faculty of Social Sciences, Universitas Negeri Medan, Medan, Indonesia \\ ${ }^{4}$ Yagasu Aceh Foundation, Medan, Indonesia \\ ${ }^{5}$ Department of Biology, Universitas Sumatera Utara, Medan, Indonesia
}

Received May 19, 2021; Revised October 29, 2021; Accepted January 16, 2022

\section{Cite This Paper in the following Citation Styles}

(a): [1] Bambang Suprayogi, J. Purbopuspito, Meilinda Suriani Harefa, G. Y. Panjaitan, Z. Nasution , "Ecosystem Carbon Stocks of Restored Mangroves and Its Sequestration in Northern Sumatra Coast, Indonesia," Universal Journal of Agricultural Research, Vol. 10, No. 1, pp. 1 - 19, 2022. DOI: 10.13189/ujar.2022.100101.

(b): Bambang Suprayogi, J. Purbopuspito, Meilinda Suriani Harefa, G. Y. Panjaitan, Z. Nasution (2022). Ecosystem Carbon Stocks of Restored Mangroves and Its Sequestration in Northern Sumatra Coast, Indonesia. Universal Journal of Agricultural Research, 10(1), 1 - 19. DOI: 10.13189/ujar.2022.100101.

Copyright $@ 2022$ by authors, all rights reserved. Authors agree that this article remains permanently open access under the terms of the Creative Commons Attribution License 4.0 International License

\begin{abstract}
The 2, 4, 6, 8, 10, 12 and 30-year restored mangroves were studied through non-destructive method by measuring their stem diameter and tree height. Two allometric references: (a) stem diameter $\left(\mathrm{D}_{30}\right)$ and (b) combined quadratic stem diameter and tree height $\left(\mathrm{D}_{30}{ }^{2} \mathrm{H}\right)$ were used to estimate aboveground and belowground vegetation carbon stocks. The soil samples were collected from different depth and analysed in laboratory for soil carbon. The objective of this study was to estimate ecosystem carbon stocks of restored mangroves and its sequestration. The growth of restored mangroves induced an increase of tree biomass and a corresponding increase in vegetation carbon stocks from $3.7 \mathrm{MgC} \mathrm{ha}^{-1}$ at 2-year to 136.8 $\mathrm{MgC} \mathrm{ha}^{-1}$ at 30-years. However, soil carbon stocks among restored mangrove plots spread randomly and didn't follow the sequence of mangrove tree ages. Average (2-30 years) mangrove ecosystem carbon in Northern Sumatra estimated by $\mathrm{D}_{30}{ }^{2} \mathrm{H}$ allometry (362.0 $\mathrm{MgC} \mathrm{ha}^{-1}$ ) was higher than that estimated by $\mathrm{D}_{30}$ allometry (344.1 $\mathrm{MgC} \mathrm{ha}^{-1}$ ). This higher trend was also followed by its carbon sequestration with values of $41.1 \mathrm{MgCO}_{2} \mathrm{e} \mathrm{ha}^{-1} \mathrm{yr}^{-1}$ estimated by $\mathrm{D}_{30}{ }^{2} \mathrm{H}$ allometry and $31.5 \mathrm{MgCO}_{2} \mathrm{e} \mathrm{ha} \mathrm{yr}^{-1}$ estimated by $\mathrm{D}_{30}$ allometry. It is concluded that the values of ecosystem carbon stock of restored mangroves and its sequestration estimated by combined quadratic stem diameter and tree height $\left(\mathrm{D}_{30}{ }^{2} \mathrm{H}\right)$ are higher than if it is
\end{abstract}

estimated by stem diameter $\left(D_{30}\right)$. The $D_{30}{ }^{2} \mathrm{H}$ value is higher because this allometry calculates the volume of the tree stem, while $\mathrm{D}_{30}$ allometry only calculates the surface of the stem. The range values of average ecosystem carbon sequestration of this study may be better used as a reference for Afforestation, Reforestation and Re-vegetation (ARR) verification than what has been used as default/conservative values.

Keywords Restored Mangroves, Carbon Stocks, Carbon Sequestration

\section{Introduction}

The concentration of $\mathrm{CO}_{2}$ in atmosphere is predicted to rise by $40 \mathrm{ppm}$ (from $370 \mathrm{ppm}$ in 2000 to $410 \mathrm{ppm}$ in 2025 (IPCC, 2001). [1] In his presentation at the World Blue Carbon Conference in Jakarta mentioned that the $\mathrm{CO}_{2}$ concentration in atmosphere was detected around $400 \mathrm{ppm}$ in 2015 and is predicted to continue increasing to $425 \mathrm{ppm}$ by 2025. The concentration of $\mathrm{CO}_{2}$ in atmosphere will continue to increase if there is no specific action on global climate change mitigation.

Mangrove ecosystem is the most effective bio-sequestration in absorbing atmospheric $\mathrm{CO}_{2}$ [2], as 
well as accumulating its unsaturated vegetation carbon and storing it in sediment for long-term period[3] that has a significant role in reducing green-house gas effects [4]. Compared to the other beach plantations such as: saltmarses, seagrass, macroalgae, coral-reef algae, microphytobenthos dan phytoplankton [5] mangrove is the most productive plant in storing carbon. The high capacity of carbon absorption may be influenced by the characteristic of mangrove trees, tidal pattern and physical factors of estuarines [6]

The reduction of $\mathrm{CO}_{2}$ in the atmosphere through bio-sequestration is important to keep global warming from exceeding $2^{\circ} \mathrm{C}$. One effort to reduce the concentration of $\mathrm{CO}_{2}$ in the air is to restore degraded mangrove ecosystem on a large scale and with sustainable efforts. The mangrove ecosystem restoration and protection program in Northern Sumatra has been carried out since 2005 and is still ongoing. This activity is not only able to restore ecological and economic functions for the community but is also able to increase the productivity of biomass for carbon reserves and sequestration. To date, 30.75 million seedlings have been planted in 12,300 ha of well-growing mangrove areas with a survival rate of 75 $92 \%$ as carbon storage. The restored mangroves have been validated and verified through the Voluntary Carbon Standard (VCS) - Afforestation, Reforestation and Re-vegetation (ARR) scheme. Thus the areas of restored mangroves that absorb excess $\mathrm{CO}_{2}$ from the atmosphere can be maintained and will not be converted again into other land-uses.

The objective of this study was to estimate ecosystem carbon stocks of serial age restored mangroves and its sequestration that estimated by two different allometries. Identified challenges of this study whether innovation of carbon accounting methodology and accountability value generated by this study are in conformity with international standard; as well as whether the range of serial age carbon stocks and carbon sequestration can be used as a reference for carbon verification rather than the use of default/conservative values.

\section{Study Area and Method}

\section{Study sites}

Data for ecosystem carbon sequestration of $2-30$ year restored mangroves were collected from 5 villages in Northern Sumatra coast: Percut, Tanjung Rejo, Pangkalan Siata, Jaring Halus and Pangkalan Gading. Growth parameters (stem diameter and tree heigth) and soil samplings were collected for biomass and carbon estimation (Annex 5).

\section{Biomass and carbon measurement}

All 2 - 30 year mangrove trees were recorded for species composition. Each tree was measured for stem diameter and tree height through non-destructive method. The stem diameter $30 \mathrm{~cm}$ above the highest prop-roots $\left(\mathrm{D}_{30}\right)$ was recorded in which each multi-stemmed tree was treated individually. The height of each tree from land-base to the top of canopy was also measured. The aboveground and belowground biomass of each mangrove species were estimated by two allometric equations based on diameter $\left(\mathrm{D}_{30}\right)$ and quadratic diameter-tree height $\left(\mathrm{D}_{30}{ }^{2} \mathrm{H}\right)$ variables (Annex 7). Then, the data on aboveground biomass (AGB, $\mathrm{kg}$ ) representing each tree age were calibrated into carbon stocks (AGC, $\mathrm{MgC} \mathrm{ha}^{-1}$ ).

\section{Soil samplings}

Five soil sampling plots were established at non-destructive plots, as seen in Annex 3. Soil samples were collected using soil auger at the $0-15 \mathrm{~cm} ; 15-30 \mathrm{~cm}$; $30-50 \mathrm{~cm} ; 50-100 \mathrm{~cm}$ and $100-200 \mathrm{~cm}$ soil depth. Each soil carbon sampling was accompanied by measurement of its parent material. Soil sample (30 - $50 \mathrm{~g})$ was taken at a thickness of $5 \mathrm{~cm}$ in the soil column at the mid-range estimate of each depth of soil (an example: 5-10 cm column range representing a depth range of $0-15 \mathrm{~cm}$ ). Data on physical-chemical sediment factors (soil $\mathrm{pH}$, soil temperature, sediment redox and soil texture) were collected from each plot.

Each soil sample was placed on an aluminum bowl then it was labeled with sampling location, plot code, soil depth, date and other related information. The collected sample was then dried in an oven at $600^{\circ} \mathrm{C}$ for 48 hours to keep the mass constant and then sealed in a vacuum plastic to slow down microbial activity. Each dried soil sample was analysed at the laboratory for the determination of soil density and carbon content analysis. The mangrove soil carbon sequestration was estimated by clustering method and the result was compared with other findings.

All data of soil carbon, vegetation carbon stocks, and ecosystem carbon sequestration were calculated using Excel software package. Linear and multiple regressions were established for further data analysis. Comparisons between mean data $(p<0.05)$ were analysed using the Excel Statistical package. Ecosystem carbon sequestration of restored mangroves $\left(\mathrm{MgCO}_{2} \mathrm{e} \mathrm{ha}{ }^{-1} \mathrm{yr}^{-1}\right)$ was calculated by summing up biomass- and soil carbon sequestration.

\section{Results and Discussion}

\section{Species composition}

There were 9 species found in the study sites (Table 1). Those multi-species were able to perform a good vegetation composition as an ecosystem, as part of 23 species growing naturally in mangrove ecosystem of Northern Sumatra coast.

Rhizophora apiculata and $R$. mucronata were dominant because of used for restoration program. Both species are easy and adaptive to grow at local environment. 


\section{Growth parameters}

The growth of restored mangroves increased significantly $(\mathrm{P}<0,001)$ with an increase of stem diameter, tree height and basal area (Figure 1). Average stem diameter of 2-30 year restored mangroves was $6.0 \mathrm{~cm}$ with an increase of $0.5 \mathrm{~cm} \mathrm{yr}^{-1}(\mathrm{y}=0.4083 \mathrm{x}+2.3432)$. The growth of stem diameter in this study was higher than Rhizophora mangle stem $\left(0.33 \mathrm{~cm} \mathrm{yr}^{-1}\right)$ growing at exposed sea tides in Braganca Peninsula, Northern Brazil [7] in which the stem diameter growth was only $0.12 \mathrm{~cm} \mathrm{yr}^{-1}$ when a monthly rainfall $<50 \mathrm{~mm}$. This evidence shows that mangrove growth is not only influenced by abiotic factors and competition among individuals and species but it is also influenced by local climate factors.

In general, the tree high growth of restored mangroves increased along with an increase in plant life. The average tree height of 2-30 years was $8.32 \mathrm{~m}$ with an increase rate of $0.94 \mathrm{~m} \mathrm{yr}^{-1}$. Stated that the high growth of mangrove forest in Puerto Rico was inversely related to an increase of sediment salinity through allometric equation: $y=-0.2 x+$ $16.58\left(\mathrm{R}^{2}=0.72\right)$ and no mangrove can live in salinity 70-80 ppt [8]. It seems that vegetation structure and plant growth parameters (tree density, stem diameter and tree height) were strongly influenced by salinity level of mangrove sediment.

Table 1. Number of trees, basal area and important value index of 2-30 year restored mangroves

\begin{tabular}{|c|c|c|c|c|c|}
\hline No & Spesies & NT (ind ha ${ }^{-1}$ ) & $\% \mathrm{NT}$ & BA $\left(m^{2} h a^{-1}\right)$ & IVI (\%) \\
\hline 1 & Rhizohora apiculata & 1,145 & $79.3 \%$ & 497.7 & 228.3 \\
\hline 2 & Rhizophora mucronata & 154 & $10.7 \%$ & 14.9 & 24.2 \\
\hline 3 & Excoecaria agallocha & 27 & $1.9 \%$ & 7.5 & 10.0 \\
\hline 4 & Avicennia officinalis & 40 & $2.8 \%$ & 6.8 & 9.4 \\
\hline 5 & Bruguiera sexangula & 34 & $2.4 \%$ & 4.5 & 2.1 \\
\hline 6 & Xylocarpus granatum & 35 & $2.4 \%$ & 5.4 & 10.7 \\
\hline 7 & Bruguiera parviflora & 6 & $0.4 \%$ & 2.1 & 9.2 \\
\hline 8 & Sonneratia alba & 1 & $0.1 \%$ & 6.6 & 1.4 \\
\hline \multirow[t]{2}{*}{9} & Avicennia marina & 1 & $0.1 \%$ & 3.1 & 4.8 \\
\hline & Total & 1,443 & $100.0 \%$ & 548.6 & 300.0 \\
\hline
\end{tabular}
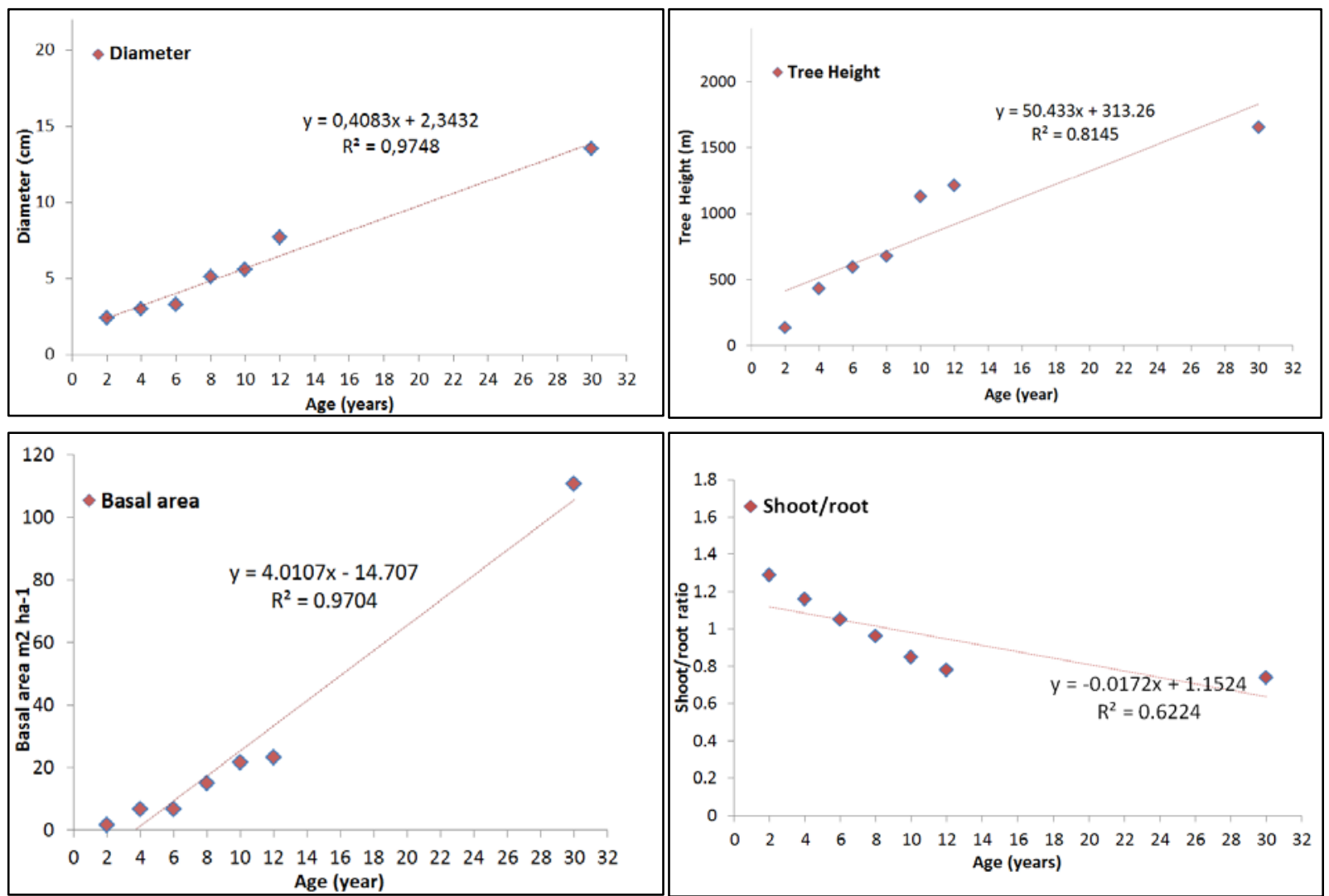

Figure 1. Average growth of stem diameter, tree height, basal area and shoot/root ratio of restored mangroves 
The stem diameter and tree height increased as an increase of tree age. While basal area varied among individual tree and didn't follow rules of tree age. The average basal area of 2-30 year trees was $26.5 \mathrm{~m}^{2} \mathrm{ha}^{-1}$ with an increase of $2.6 \mathrm{~m}^{2} \mathrm{ha}^{-1} \mathrm{yr}^{-1}(\mathrm{y}=4.0107 \mathrm{x}-14.707)$. The average increase of basal area in this study was higher than the increase of individual Sonneratia alba (7.0 to $79.6 \mathrm{~m}^{2}$ $\mathrm{ha}^{-1} \mathrm{yr}^{-1}$ ) and Bruguiera gymnorhiza (4.8 - $27.4 \mathrm{~m}^{2} \mathrm{ha}^{-1} \mathrm{yr}^{-1}$ ) growing at mangrove forests in Micronesia [9].

Basal area increased from $1.6 \mathrm{~m}^{2} \mathrm{ha}^{-1}$ at 2-year to 110.8 $\mathrm{m}^{2}$ ha $^{-1}$ at 30 -year old. The basal area of 30 year $R$. apiculata $\left(110.8 \mathrm{~m}^{2} \mathrm{ha}^{-1}\right)$ in this study was much larger than the basal area of the same species living at natural mangrove forest in Maluku - Eastern Indonesia $23.97 \mathrm{~m}^{2}$ $\mathrm{ha}^{-1}$ [10], in Ranong - Southern Thailand $23.97 \mathrm{~m}^{2} \mathrm{ha}^{-1}$ [11] and in Talidendang Riau - East Sumatra $29.5 \mathrm{~m}^{2} \mathrm{ha}^{-1}$ [12]. However, the increase trend of basal area of this study was in opposite with basal area increment of Rhizophora apiculata forests in the Mekong delta, Vietnam [13]. The differences in average basal area in specific sites may be significantly influenced by the hydro-geomorphological zone where the plant grows.

The shoot/root ratio of restored mangroves in this study was inversely proportional to the growth parametes. An average increase of tree age decreased $6 \%$ shoot/root ratio (S/R ratio) from 1.29 at 2 years; 1.16 at 4 years; 1.05 at 6 years; 0.96 at 8 years; 0.85 at 10 years; 0.78 at 12 years; and 0.74 at 30 years. This finding showed that mangrove rooting system was much more intensive and expansive when the trees grow up. This expansive rooting occured when the trees become older that makes easier taking up soil nutrients with its extensive rooting systems.

\section{Vegetation carbon stocks}

In principle, mangrove ecosystem is an effective carbon accumulation machine [14]. Measuring an ability of restored mangrove ecosystem in absorbing and storing carbon is the core of this study. The carbon is stored in plant components and sediments. However, part of vegetation carbon will be gone due to decomposed deadwoods and litters as a food chain of fauna or flowing to the sea through tidal pattern.

Belowground vegetation carbon stocks of 2-30 year restored mangroves estimated by $D_{30}$ and $D_{30}{ }^{2} \mathrm{H}$ allometries increased with increasing age of trees (Annex 7), with exception of the 6-year (9.5 $\mathrm{MgC} \mathrm{ha}^{-1}$ ) is less than the 4-years (10.1 $\mathrm{MgC} \mathrm{ha}^{-1}$ ). The belowground carbon stock of this study (22.3 $\mathrm{MgC} \mathrm{ha}^{-1}$ ) was higher than the stocks in Segara Anakan mangrove forest (2.6 $\left.\mathrm{MgC} \mathrm{ha}^{-1}\right)$, Bunaken National Park (13.7 $\mathrm{MgC} \mathrm{ha}^{-1}$ ) and Tanjung Puting National Park (18.1 MgC ha-1) - Central Kalimantan [15].

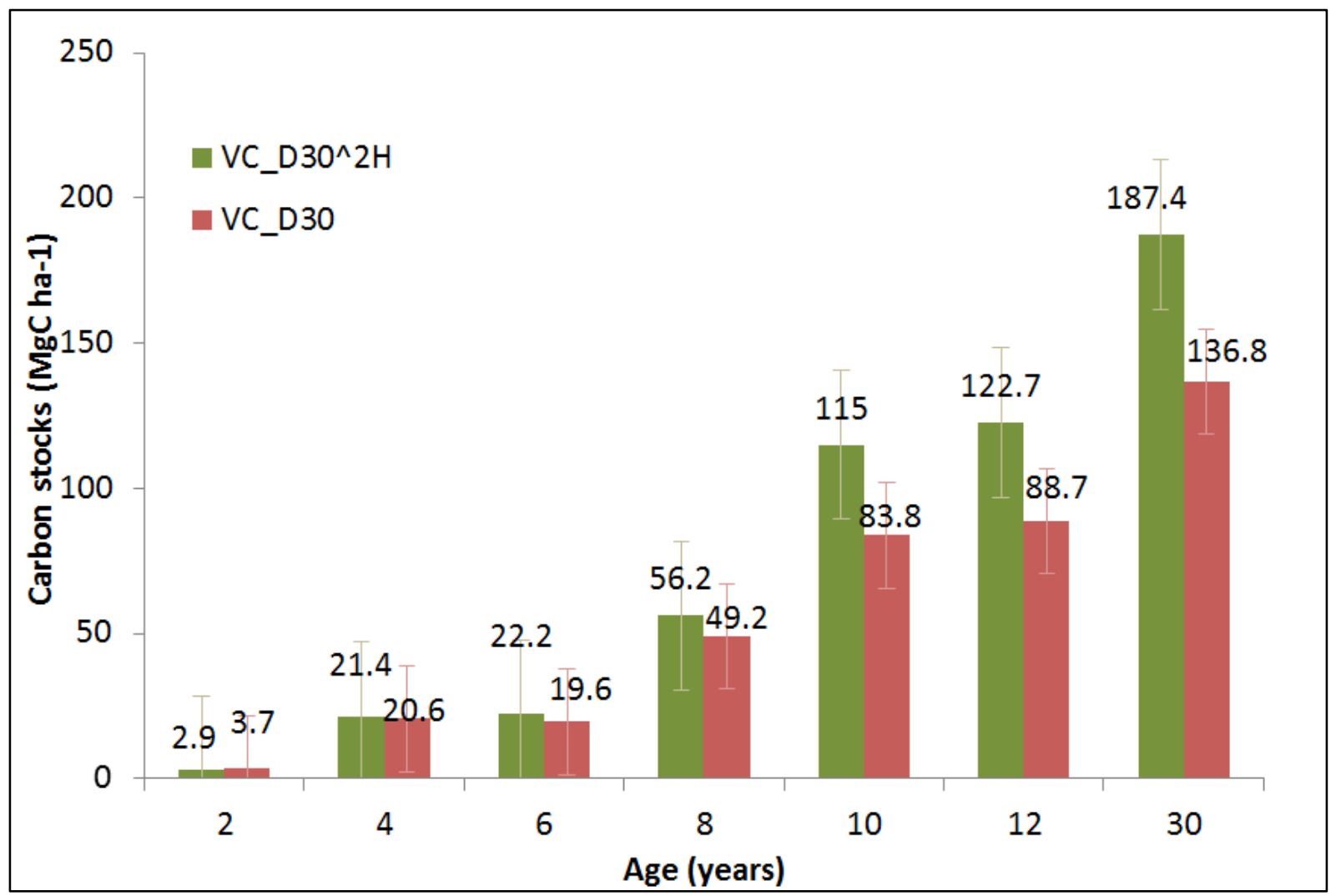

Figure 2. Vegetation carbon stocks of restored mangroves estimated by two allometries 
The 30-year above-ground carbon stock of this study (92.4 MgC ha-1) was much lower than the aboveground carbon stock (178.2 $\mathrm{MgC} \mathrm{ha}^{-1}$ ) and belowground carbon stock (146.3 $\left.\mathrm{MgC} \mathrm{ha}^{-1}\right)$ of natural mangrove forest in Puerto Rico[16] and the stock in Tanjung Puting National Park (124.3 MgC ha-1 $)$ - West[15].

Aboveground vegetation carbon stocks estimated by $\mathrm{D}_{30}$ allometry significantly increased from $1.7 \mathrm{MgC} \mathrm{ha}^{-1}$ at 2-year to $92.4 \mathrm{MgC} \mathrm{ha}^{-1}$ at 30-year old, but the 6-years $\left(10.1 \mathrm{MgC} \mathrm{ha}^{-1}\right)$ had a lower stock than the 4-years $(10.5$ MgC ha ${ }^{-1}$ ). The aboveground stocks estimated $\mathrm{D}_{30}{ }^{2} \mathrm{H}$ allometry consistently increased from $0.9 \mathrm{MgC} \mathrm{ha}^{-1}$ at 2-year to $143.1 \mathrm{MgC} \mathrm{ha}^{-1}$ at 30-year old.

The carbon stocks dominated Rhizophora mangrove forest (123 MgC ha-1) in Hinchinbrook Chanel, Australia [17] was on the range aboveground carbon stocks of 30-year restored mangroves (92.4-143.1 $\mathrm{MgC} \mathrm{ha}^{-1}$ ) of this study. The range aboveground carbon stocks in this study was lower than aboveground carbon stocks (159 MgC ha-1) across the Indo-Pacific [18] aboveground stocks of 18-year R. apiculata (193 MgC ha-1) and 80-year R. apiculata (312 $\mathrm{MgC} \mathrm{ha}{ }^{-1}$ ) in Peninsular Malaysia, and R. stylosa (297 $\mathrm{MgC} \mathrm{ha}^{-1}$ ) in Queensland, Australia[18]. However, the aboveground carbon stocks in this study was higher than the aboveground carbon stocks of natural mangrove forest (7.5 MgC ha ${ }^{-1}$ ) in Segara Anakan - Central Java and (61.4 $\mathrm{MgC} \mathrm{ha}{ }^{-1}$ ) in Bunaken National Park - North Sulawesi [18].

Average (2-30 years) vegetation carbon stock estimated by $\mathrm{D}_{30}$ allometry of this study $\left(57.5 \mathrm{MgC} \mathrm{ha}^{-1}\right)$ was smaller than[19] findings at several natural mangrove forest in Indonesia: Bunaken National Park (69.2 $\left.\mathrm{MgC} \mathrm{ha}^{-1}\right)$, Kubu Raya (134.8 MgC ha ${ }^{-1}$ ), Tanjung Puting National Park (140.9 $\mathrm{MgC} \mathrm{ha}^{-1}$ ), Teminabuan (196.3 MgC ha ${ }^{-1}$ ), Timika (255.1 MgC ha ${ }^{-1}$ ), Sembilang National Park (300.5 MgC $\mathrm{ha}^{-1}$ ) and Bintuni Bay (323.6 $\left.\mathrm{MgC} \mathrm{ha}^{-1}\right)$, but it was higher than the mangrove carbon stock in Cilacap (6.9 $\left.\mathrm{MgC} \mathrm{ha}^{-1}\right)$. The significant different may be due to the referenced carbon stocks collected from older age of natural mangrove forests, while the average stock in this study was to include the young planted mangroves starting from 2-year old. The differences of carbon stocks in different locations may be influenced by different mangrove age, soil fertility, individual tree growth, species, biotic and abiotic factors, and local climate between restored mangroves and natural mangrove forests.

The increase trend of mangrove carbon biomass until 30 -year old in this study was consistent with[6] modified from[20] that the biomass of Rhizophora apiculata in the Mekong delta - Vietnam still increases until 40-year old. Moreover[6] modified from[21] also mentioned the development of mangrove ecosystem along the French Guiana can effectively accumulate carbon until 70-year old mangroves in which their growth is divided into 3 stages: early development ( $0-15$ years), maturity ( $15-70$ years) and senescence (after 70 years).

Difference in mean value of vegetation carbon stocks between $\mathrm{D}_{30}{ }^{2} \mathrm{H}$ allometry and $\mathrm{D}_{30}$ allometry at 2-30 years was 17.7 $\mathrm{MgC} \mathrm{ha}^{-1}$ (22.9\%). It means that carbon estimation using $\mathrm{D}_{30}$ allometry can be used as a conservative value and the stcok of $\mathrm{D}_{30}{ }^{2} \mathrm{H}$ allometry will be as a maximum estimation. This conservative value will be a strenght of $\mathrm{D}_{30}$ allometry that will not be over-prediction in estimating carbon stocks on specific site. However, the vegetation carbon stocks estimated by $\mathrm{D}_{30}$ and $\mathrm{D}_{30}{ }^{2} \mathrm{H}$ allometries need to be compared with the stocks calculated by the destructive study. The comparison values between both calculation methods will figure the accuracy level to the real condition in the field.

\section{Vegetation carbon lost}

Mangrove ecosystem as a $\mathrm{CO}_{2}$ reservoir is able to accumulate and store carbon, but it will be released into atmosphere if the vegetation is cut or cleared. The vegetation carbon stocks in this study are divided into ideal- and actual conditions (Table 2). Ideal condition means that the vegetation carbon stocks from undisturbed tree biomass are considered intact. The actual condition is disrupted, indicating that carbon stocks from tree biomass are impaired. The actual tree conditions being sampled in the plots were in disturbed condition. The disturbance was indicated by the presence of standing trees but some parts of tree components such as branches, twigs, leaves/ fruits/flowers or proof-roots were lost.

Table 2. Average vegetation carbon stocks of 2-30 year restored mangroves in ideal- and actual condition

\begin{tabular}{cccccccc}
\hline & \multicolumn{4}{c}{ Vegetation carbon stocks (MgC ha-1) } \\
\cline { 2 - 7 } & \multicolumn{2}{c}{ Ideal condition } & \multicolumn{2}{c}{ Actual condition } & \multicolumn{2}{c}{ Carbon lost } \\
Parameters & $\mathbf{X}$ & $\pm \mathbf{s d}$ & $\mathbf{X}$ & \pm sd & $\mathbf{X}$ & \pm sd \\
\hline $\mathrm{D}_{30}{ }^{2} \mathrm{H}$ allometry & 76.8 & \pm 33.6 & 75.4 & \pm 33.5 & 1.4 & $\pm 0,1$ \\
$\mathrm{D}_{30}$ allometry & 59.2 & \pm 26.0 & 57.5 & \pm 26.0 & 1.7 & $\pm 0,0$ \\
\hline $\mathrm{D}_{30}{ }^{2} \mathrm{H}-\mathrm{D}_{30}$ allometry & 17.7 & $\pm 5,4$ & 17.9 & $\pm 5,3$ & & \\
\hline
\end{tabular}

$\mathrm{X}$ : mean; sd : deviation standard; n-plot $=35$ 
Average vegetation carbon loss of restored mangroves estimated by $\mathrm{D}_{30}$ allometry $\left(1.7 \mathrm{MgC} \mathrm{ha}^{-1}\right.$ ) was higher than carbon lost estimated by $\mathrm{D}_{30}{ }^{2} \mathrm{H}$ allometry $\left(1.4 \mathrm{MgC} \mathrm{ha}^{-1}\right)$. Loss of carbon stocks of restored mangroves increased with age. Field observation showed that older trees tended to be more vulnerable for community use. Access to restored mangroves is one of important factors of losing carbon where the mangroves within walking distance are fragile from illegal cutting. Loss of carbon stocks due to natural factors and community actions on mangroves cannot be avoided, but it can be minimized through awareness program and law-enforcement.

The extent of mangrove forest ecosystem in some countries is reduced by almost $50 \%$ due to human influences, in particular due to deforestation and land conversion [22]. The impact of mangrove forest loss is declining ability of ecosystem to sequester carbon. When the mangrove ecosystem is gone or degraded, the organic carbon materials stored for decades or even thousand years will be released back on the form of $\mathrm{CO}_{2}$ emissions into atmosphere.

Mangrove ecosystem can contribute to climate change in the case of increasing atmospheric $\mathrm{CO}_{2}$ concentration if the ecosystem is converted to other land-use. Estimated that loss of 35\% of the world's mangrove ecosystems will result in carbon emissions of 3.8 x 1014 gC of vegetation carbon stored in above-ground biomass. This figure was considered to be below the forecast because it has not included total sub-surface biomass and tree canopy [22].

Globally deforestation mangrove forests contributed to

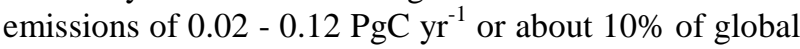
deforestation emissions [18]. Conversion of mangrove ecosystem into farmland in Malaysia produced $75 \mathrm{MgC}$ $\mathrm{ha}^{-1} \mathrm{yr}^{-1}$ soil carbon emissions from hundred years of sediment accumulation into the atmosphere, which is equivalent to 50 times average soil carbon sequestration [18]. $\mathrm{CO}_{2}$ emissions from mangrove ecosystem also occur in Indonesia because the deforestation rate is very fast and ranks on the top in the world. Mangrove degradation in Indonesia was caused by conversion and land-use change for intensive fish- and shrimp ponds; tree cutting for charcoal, construction and settlement as well as other commercial activities. Over 2 million hectares of mangrove ecosystem in Indonesia have been damaged in the last 50 years.

In addition, preliminary study of [23] showed average aboveground carbon sequestration at Percut natural mangrove forest was $9.98 \mathrm{MgC} \mathrm{ha}^{-1} \mathrm{yr}^{-1}$. If the data were converted to the total loss of 69,304 ha mangroves in North Sumatera coast, the mangrove deforestation in this

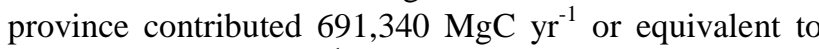
2,537,219 $\mathrm{MgCO}_{2} \mathrm{e} \mathrm{yr}^{-1}$ carbon emissions to atmosphere. The carbon stocks in study sites will decrease drastically if there are no mangrove restoration and protection efforts. Assuming mangrove degradation of $4 \%$ per year, the ecosystem carbon stocks will decrease by $30 \%$ for 30 years. The response to carbon losses is to increase mitigation efforts that involve local communities in managing mangrove ecosystem.

\section{Soil carbon stocks}

Mangroves have stilt- or prop-roots system that can stick into sediment and allow oxygen entering into the submerged roots. Such complex rooting structures can slow down the flow of water at high tides that cause water-borne materials to settle on the sediment surface[22] Therefore the soil carbon stocks are not only derived from litters and deadwood components of mangrove plant itself but also come from outside mangrove ecosystem in the form of particles trapped by root system.

The maximum soil depth varied and significantly different among the plots, such as $267 \mathrm{~cm}$ at 4-year plot and $300 \mathrm{~cm}$ at 2- and 10-year plots (Annex 8). The soil density of 30-year plot (0.96; 0.92; 0.97; 0.93 dan $0.99 \mathrm{~g} \mathrm{~cm}^{-3}$ ) didn't follow the level of soil depth. The pattern of SD variation in this study was similar to [24] finding but its range $\left(0.92-0.97 \mathrm{~g} \mathrm{~cm}^{-3}\right)$ was much higher than soil density of natural mangrove forests in Palau (0.20 - $0.25 \mathrm{~g}$ $\left.\mathrm{cm}^{-3}\right)$ and in Micronesia $\left(0.37-0.51 \mathrm{~g} \mathrm{~cm}^{-3}\right)$.

The range of average soil density in this study $(0.71-$ $1.17 \mathrm{~g} \mathrm{~cm}^{-3}$ ) was higher than [19] findings at several natural mangrove forests in Indonesia $\left(0.28-0.76 \mathrm{~g} \mathrm{~cm}^{-3}\right)$. Average C-content in this study (5.32\%) was also smaller than the mean C-content $(9.60 \%)$ at several natural mangrove forests in Sembilang, Cilacap, Kubu Raya, Tanjung Putting, Bunaken, Teminabuan, Bintuni and Timika [19]. 
Table 3. Average soil carbon stocks based on soil depth and tree age plots

\begin{tabular}{|c|c|c|c|c|c|}
\hline \multicolumn{6}{|c|}{ Average soil carbon stocks (MgC ha') } \\
\hline \multicolumn{3}{|c|}{ Based on tree age plots } & \multicolumn{3}{|c|}{ Based on soil depth } \\
\hline Tree age plots & $\mathbf{X}$ & \pm sd & Soil depth & $\mathbf{X}$ & $\pm \mathbf{s d}$ \\
\hline 2 years & 80.1 & \pm 10.0 & $0-15 \mathrm{~cm}$ & 12.7 & \pm 4.5 \\
\hline 4 years & 167.2 & \pm 36.8 & $15-30 \mathrm{~cm}$ & 12.6 & \pm 3.5 \\
\hline 6 years & 618.0 & \pm 180.9 & $30-50 \mathrm{~cm}$ & 18.3 & \pm 6.5 \\
\hline 8 years & 207.8 & \pm 47.5 & $50-100 \mathrm{~cm}$ & 49.5 & \pm 15.9 \\
\hline 10 years & 182.6 & \pm 38.8 & $100-200 \mathrm{~cm}$ & 192.5 & \pm 81.6 \\
\hline 12 years & 511.5 & \pm 189.0 & Total all depth & 285.5 & \pm 81.6 \\
\hline 30 years & 231.5 & \pm 67.9 & & & \\
\hline (2-30 years) & 285.5 & \pm 81.6 & & & \\
\hline (2-12 years) & 294.5 & \pm 83.8 & & & \\
\hline (12-30 years) & 371.5 & \pm 128.4 & & & \\
\hline
\end{tabular}

$\mathrm{X}=$ average value $; \mathrm{sd}=$ standard deviation; $\mathrm{n}$-plot $=35$

Average mangrove soil carbon stocks increased according to the soil depth (Table 3). This indicated that the soil carbon stocks didn't increase according to the growth of decomposed litters and deadwoods from sediment surface. Litters and accumulated necromasses were degraded by micro-organisms through aerobic and anaerobic respiration processes [25]. The magnitude of soil carbon stocks is more influenced by the ability of sediments to store carbon through soil evolution of allochthonous sedimentation process rather than by biomass decomposition. It was proven that the soil carbon stocks at a depth of $>100 \mathrm{~cm}$ were much larger than the stocks at soil surface due to their stable condition without being influenced by tidal patterns.

Soil carbon stocks at all depths differed significantly $(\mathrm{P}<0.01)$ across all plots of different age groups. The average of soil carbon stocks of 6-year plots (618.0 MgC $\mathrm{ha}^{-1}$ ) was significantly much higher than the 30-year plots (231.5 $\mathrm{MgC} \mathrm{ha}^{-1}$ ). The smallest soil carbon stock was located at 2-year plot $\left(80.1 \mathrm{MgC} \mathrm{ha}^{-1}\right)$ and the largest was at 6-year plot (618.0 $\left.\mathrm{MgC} \mathrm{ha}^{-1}\right)$. This indicated that soil carbon stocks were more influenced by historical factors of soil carbon accumulation and sedimentation ability of mangrove ecosystem rather than by decomposition process of tree biomass. Mangrove root production significantly affects soil composition rather than litter fall decomposition [26]. Average sediment accretion rates of mangrove sediments worldwide were $5.0 \mathrm{~mm} \mathrm{yr}^{-1} 1$ [13].

The average (2-30 years) soil carbon stock in this study (285.5 MgC ha ${ }^{-1}$ ) was smaller than Murdiyarso et al. (2015) findings at several natural mangrove forests in Indonesia: Bunaken National Park (811.6 MgC ha ${ }^{-1}$ ), Kubu Raya (620.9 MgC ha $\left.{ }^{-1}\right)$, Tanjung Puting National Park $(1,059.2$
MgC ha-1), Teminabuan (660.5 MgC ha ${ }^{-1}$ ), Timika (965.1 MgC ha ${ }^{-1}$ ), Sembilang National Park (979.5 MgC ha ${ }^{-1}$ ), Bintuni Bay (1,014.8 $\left.\mathrm{MgC} \mathrm{ha}^{-1}\right)$ and Cilacap (571.6 MgC $\left.\mathrm{ha}^{-1}\right)$. The referenced soil carbon stocks may be from natural mangrove forests, while the stock in this study was in restored mangroves. The differences of soil carbon stocks in different locations may be influenced by different sediment conditions, soil fertility and abiotic factors.

\section{Ecosystem carbon stocks}

Mangrove ecosystem storing $\mathrm{CO}_{2}$ from biomass of plant components is called vegetation carbon stock. While, the decomposed biomass and deposited soil in sediment is called organic carbon soil. The carbon stocks of mangrove ecosystem represent total amount of vegetation carbon that includes dead woods and litters, and organic soil carbon (Figure 2).

Mangrove ecosystem is able to store larger soil carbon than those stored in vegetation. The estimated carbon stock by two allometries varied greatly and didn't follow the tree age-increasing pattern. The differences of ecosystem carbon stocks among plots were more determined by $62.9-$ 95.6.9\% of soil carbon stocks. The percentage of soil carbon decreased when the mangroves growing older from $95.6 \%$ at 2-year plot to $62.9 \%$ at 30-year plot (Annex 14). The older trees can produce more percentage of vegetation carbon stocks because of increasing its growth parameters. However, the 6-year plot (96.9\%) and 12-year plot (85.2\%) didn't follow the age plot pattern because those plots consist of higher organic soil stocks compared to their vegetation carbon stocks. 


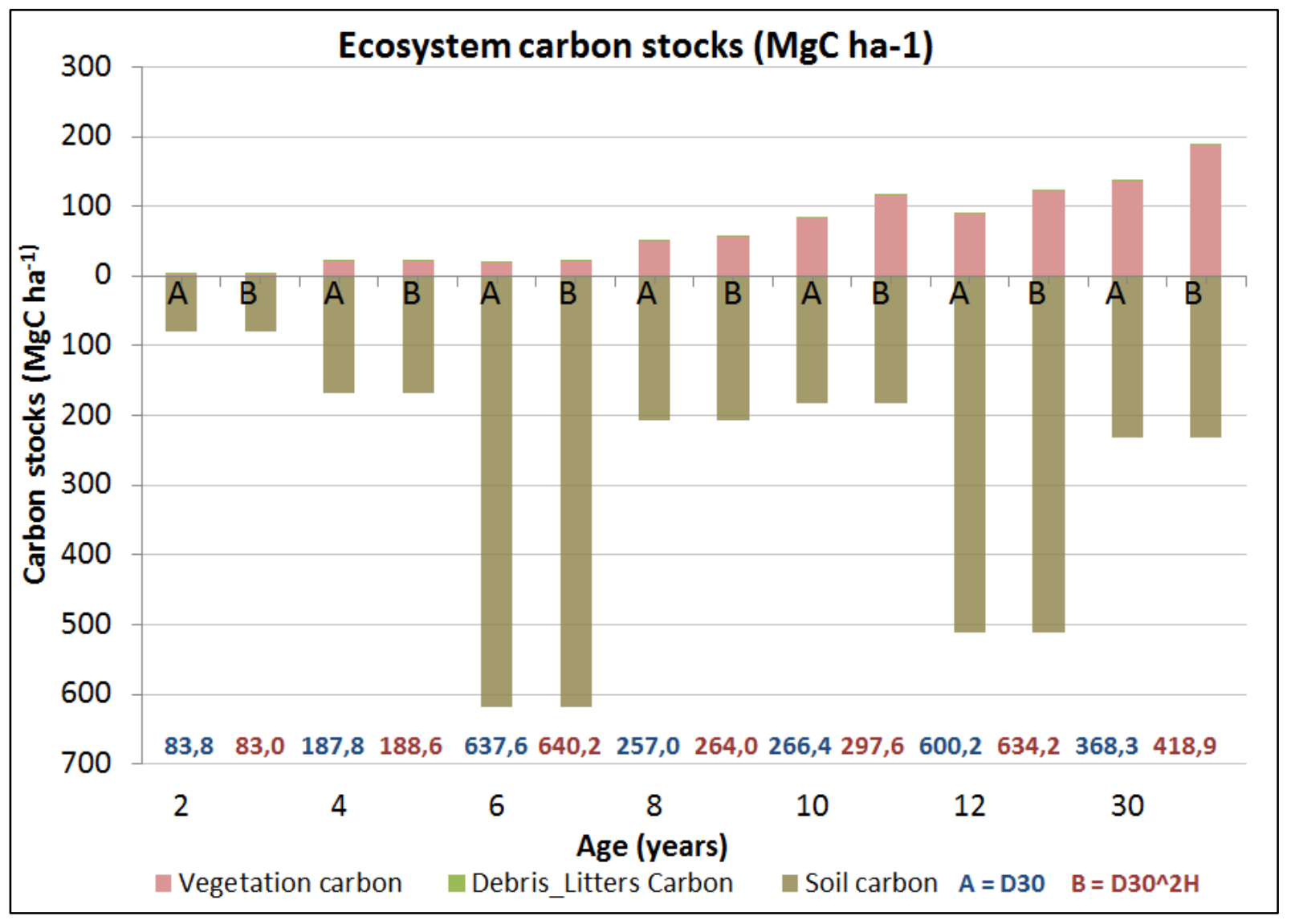

Figure 3. Histogram of ecosystem carbon stocks of restored mangroves

In actual condition, the average ecosystem carbon stocks estimated by $\mathrm{D}_{30}$ allometry (344.1 $\left.\mathrm{MgC} \mathrm{ha}^{-1}\right)$ was lower than the stocks estimated by $\mathrm{D}_{30}{ }^{2} \mathrm{H}$ allometry $(362.0 \mathrm{MgC}$ $\mathrm{ha}^{-1}$ ), with the differences of $5.2 \%$. The carbon stocks in this study were on the range value of carbon stocks (50 to $800 \mathrm{MgC} \mathrm{ha}^{-1}$ ) in Zambesi river delta, Mozambique reported by[13]; in Mahajamba Bay, Madagascar[27] in Kenya[27]; and at Sofala bay [28]

In fact, the stocks of this study (344.1 - $362.0 \mathrm{MgC} \mathrm{ha}^{-1}$ ) were lower than the ecosystem carbon stock of in Geza mangrove forest (414.6 MgC ha-1) and Mtimbwani (684.9 MgC ha ${ }^{-1}$ ) - Tanzania where their soil carbon content reached 65\% [29]. Furthermore, the carbon in this study was far below the value of ecosystem carbon stocks in Indo-West Pacific that varied from 830 to $1,131 \mathrm{MgC} \mathrm{ha}^{-1}$ [29]; and 18-year R. apiculata (1,117 $\left.\mathrm{MgC} \mathrm{ha}^{-1}\right)$ in Peninsular Malaysia, 6-year R. apiculata (1,179 $\left.\mathrm{MgC} \mathrm{ha}^{-1}\right)$ in Southern Vietnam, 25-year R. apiculata (808 $\mathrm{MgC} \mathrm{ha}^{-1}$ ) and 3-year of Ceriops decandra (600 $\mathrm{MgC} \mathrm{ha}^{-1}$ ) in Southern Thailand, Kandelia kandel (619 $\left.\mathrm{MgC} \mathrm{ha}^{-1}\right)$ in Southern China, and Rhizophora stylosa (863 $\mathrm{MgC} \mathrm{ha}^{-1}$ ) and Avicennia marina (662 $\mathrm{MgC} \mathrm{ha}^{-1}$ ) in Western Australia[29]. Differences of inter-site carbon stocks are due to differences in plant age, vegetation structure, species composition, individual species capability, sediment conditions and local climate of each location.

\section{Soil carbon sequestration}

The average sequestration of stored organic soil carbon (organic carbon burial) in the sediment is ideally calculated by the measurement time interval of soil carbon evolution [29]. Due to very long period in collecting sequence data of soil evolution, the clustered/grouped approach was applied in estimating the carbon sequestration rate in this study. The soil carbon sequestration was estimated by grouped areas where have similar soil and environmental conditions, and was not based on the plant age groups.

The sequestration regression of soil carbon based on in Sei Meran and Tanjung Rejo clustering system was $\mathrm{Y}=$ $9.34 * \mathrm{X} \wedge{ }^{-0.188}$ (Annex 17). The average soil carbon sequestration of this study was $1.81 \pm 0.18 \mathrm{MgC} \mathrm{ha}^{-1} \mathrm{yr}^{-1}$ or equivalent to $6.62 \pm 0.66 \mathrm{MgCO}_{2} \mathrm{e} \mathrm{ha}{ }^{-1} \mathrm{yr}^{-1}$. The sequestration value of this clustered soil carbon was the same to [30] finding (1.81 $\mathrm{MgC} \mathrm{ha}^{-1} \mathrm{yr}^{-1}$ ) on mangrove forest in Australia.

This soil carbon sequestration of this study was higher than the default value of mangrove soil carbon sequestration of Wetland supplement $1.62 \mathrm{MgC} \mathrm{ha}^{-1} \mathrm{yr}^{-1}$ (IPCC, 2014), average annual rates of carbon burial in mangrove forests worldwide $1.74 \mathrm{MgC} \mathrm{ha}^{-1} \mathrm{yr}^{-1}$ [13], organic carbon burial rates in mangroves sediments 1.63 $\mathrm{MgC} \mathrm{ha}{ }^{-1} \mathrm{yr}^{-1}$ [13] and soil carbon mangrove ecosystem in Mumbai-India 1.50 $\mathrm{MgC} \mathrm{ha}^{-1} \mathrm{yr}^{-1}$ [13]. However the 
carbon sequestration of this study was lower than [13] finding 2.10 $\mathrm{MgC} \mathrm{ha}^{-1} \mathrm{yr}^{-1}$ and [13] study 2.26 $\mathrm{MgC} \mathrm{ha}^{-1}$ $\mathrm{yr}^{-1}$.

\section{Ecosystem carbon sequestration}

Mangrove ecosystem provides benefits of environmental services in the form of carbon sequestration [31] which is essential to control the concentration of greenhouse gas emissions. The ecosystem is able to accumulate carbon without saturation and store it in the sediment [31]. The process of accumulating $\mathrm{C}$ in leaves, fruits, flowers, stems, branches, twigs, stumps and proop-roots is called sequestration process of carbon. This sequestration involves carbon capture and storage of carbon dioxide $\left(\mathrm{CO}_{2}\right)$ for a long time [31]. The carbon sequestration can be derived from the ability of the mangrove tree themselves and due to support of surrounding environmental factors such as tidal patterns and physical factors of estuary area ([32];[6]). The carbon sequestration of restored mangroves estimated by two different allometries can be seen in Figure 4.

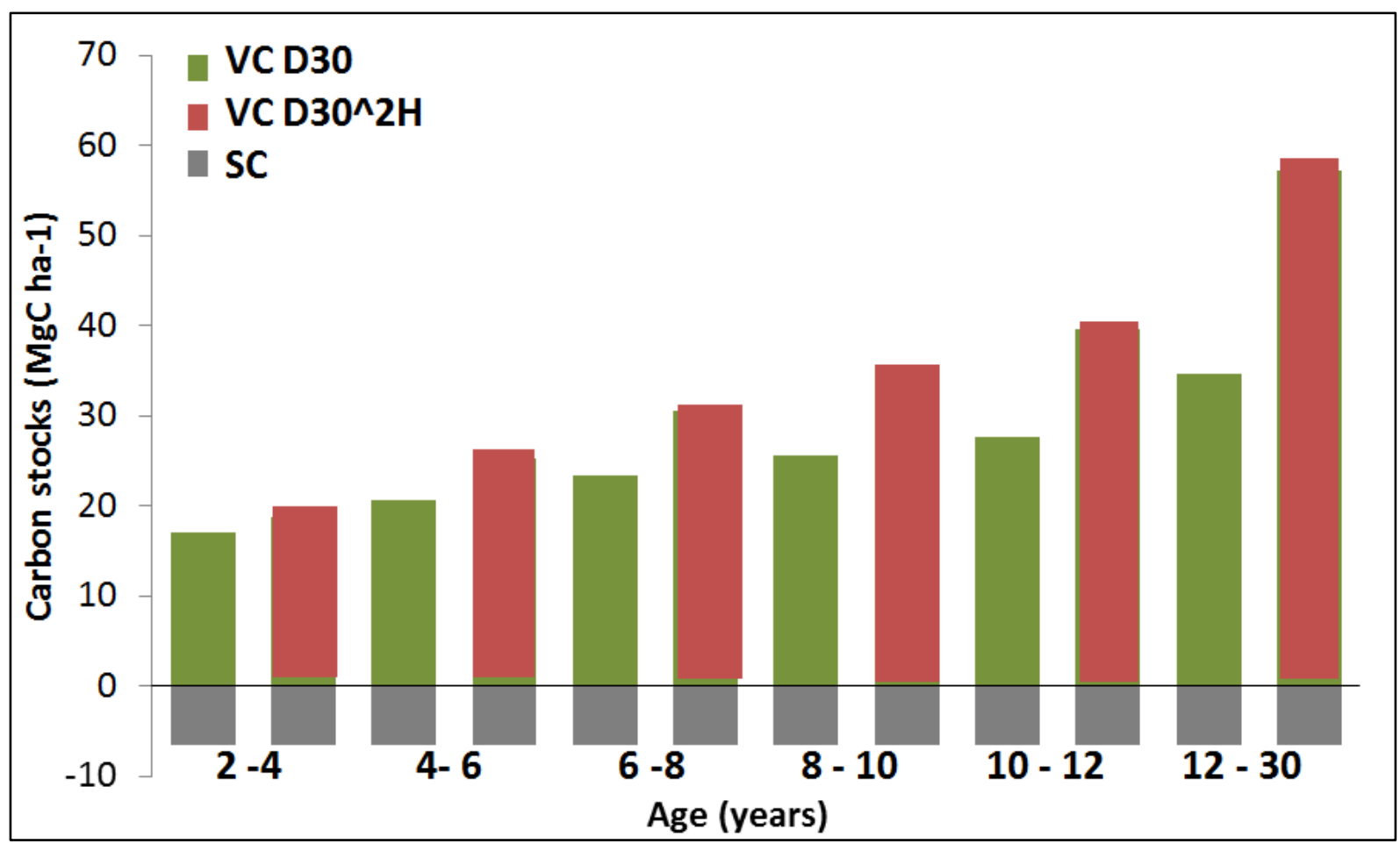

Figure 4. Ecosystem carbon sequestration based on $\mathrm{D}_{30}$ and $\mathrm{D}_{30}{ }^{2} \mathrm{H}$ allometries

Table 4. Average ecosystem carbon sequestration of restored mangroves

\begin{tabular}{ccccc}
\hline & \multicolumn{3}{c}{ Average carbon stocks $\left(\mathbf{M g C ~ h a}^{-1}\right)$ and sequestration $\left(\mathbf{M g C O}_{2} \mathbf{e ~ h a}^{-1} \mathbf{~ y r}^{-1}\right)$} \\
\cline { 2 - 5 } Tree ages & \multicolumn{2}{c}{$\boldsymbol{D}_{30}$ allometry } & \multicolumn{2}{c}{$\mathbf{D}_{30}{ }^{2} \mathbf{H}_{\text {allometry }}$} \\
2-12 years & C-stocks & $\mathbf{C O}_{2}$ sequestration & C-stocks & $\mathbf{C O}_{2}$ sequestration \\
\hline 2-30 years & 339.9 & 29.5 & 352.3 & 36.5 \\
12-30 years & 344.1 & 31.5 & 362.0 & 41.1 \\
\hline
\end{tabular}

n plot $=35$ 
Average carbon stocks of 2-30 year restored mangroves estimated by both allometries ranged from 344.1 to 362.0 $\mathrm{MgC} \mathrm{ha}{ }^{-1}$. These values are smaller than the average carbon stock of mangrove forest ecosystems in the tropics $\left(1,023 \mathrm{MgC} \mathrm{ha}^{-1}\right)$ where the soil carbon stocks varied between 49 - 98\% at 0.5 - $3 \mathrm{~m}$ soil depth [18].

In addition, the average (12-30 years) ecosystem carbon stock estimated by diameter variable of this study (485.3 $\mathrm{MgC} \mathrm{ha}^{-1}$ ) is smaller than[19] finding at several natural mangrove forests in Indonesia: Cilacap (592.8 $\mathrm{MgC} \mathrm{ha}^{-1}$ ), Kubu Raya (794,2 MgC ha ${ }^{-1}$ ), Teminabuan (910.9 MgC $\left.\mathrm{ha}^{-1}\right)$, Bunaken National Park (938.5 MgC ha $\left.{ }^{-1}\right)$, Tanjung Puting National Park (1,240.0 MgC ha $\left.{ }^{-1}\right)$, Timika (1,275.2 $\left.\mathrm{MgC} \mathrm{ha}^{-1}\right)$, Sembilang National Park (1,319.1 MgC haand Bintuni Bay (1.396 $\mathrm{MgC} \mathrm{ha}^{-1}$ ). The referenced ecosystem carbon stocks were from soil carbon stocks, while the soil carbon in this study was much lower than the referenced stocks. An average ecosystem carbon of natural mangrove forests in the tropics was $1,023 \mathrm{MgC} \mathrm{ha}^{-1}$ that contains $49-98 \%$ organic soil carbon[19]. The differences of carbon stocks in different locations may be influenced by soil carbon component, different mangrove age, soil fertility, individual tree growth, species, biotic and abiotic factors, and local climate between restored mangroves and natural mangrove forests.

The average ecosystem carbon sequestration had consistently increased considerably with age. The carbon sequestration estimated by $\mathrm{D}_{30}$ allometry for an average age of 2-12 years; 2-30 years and 12-30 years were respectively 29.5; 31.5 and $37.7 \mathrm{MgCO}_{2} \mathrm{e} \mathrm{ha}^{-1} \mathrm{yr}^{-1}$, while the average carbon sequesration estimated by $\mathrm{D}_{30}{ }^{2} \mathrm{H}$ alometry was $36.5 ; 41.1$ and $55.1 \mathrm{MgCO}_{2} \mathrm{e} \mathrm{ha}^{-1} \mathrm{yr}^{-1}$. Two alometries show similar trend that the highest carbon production rate of mangroves when they grow after 12 year old. The range of carbon sequestration of this study was higher than [21] finding on carbon sequestration in mangrove ecosystem of Mumbai-India $\left(12.08 \mathrm{MgCO}_{2} \mathrm{e}\right.$ $\left.\mathrm{ha}^{-1} \mathrm{yr}^{-1}\right)$.

[33] mentioned that the biomass of Rhizophora apiculata in the Mekong delta, Vietnam still increase until 40-year old. Moreover, mangroves at French Guiana effectively accumulated carbon from 15 to 70 -year old [34] modified from [21]. Therefore, it is important to conduct more study whether the restored mangroves in the study sites can still effectively sequester carbon after 30 year old.

Carbon production of mangrove ecosystem is determined by the rates of primary productivity and decomposition. An ability of mangrove ecosystem to sequester carbon is influenced by respiration time. The high rate of carbon sequestration occurred during spring tides rather than neap tides. The ecosystem carbon production is strongly influenced by climate factors such as temperature and precipitation [35]. Therefore, the design of mangrove restoration program should be based on carbon cyclus model and should consider tidal pattern in anticipating sea rise effects in the future [36].

To prevent the decline in ecosystem carbon sequestration, it is necessary to conduct tree thinning or pruning efforts starting from 8 years old. These actions will give more space to the trees who live on the middle site to get enough sunlight for their photosynthetic process. Storing $\mathrm{CO}_{2}$ in biomass through photosynthetic process will be a carbon source for mangrove ecosystem. In addition, it is important to let the restored mangroves be able to make their natural succession and enrichment. So that carbon sequestration can increase along with the growth of plant life due to enough space and species variation.

The comparison of sequestration values indicates that: (a) the carbon sequestration value of the ecosystem tends to increase with tree age; and (b) the sequestration value estimated by $\mathrm{D}_{30}{ }^{2} \mathrm{H}$ alometry is relatively greater compared to the sequestration value estimated by $\mathrm{D}_{30}$ allometry. The use of $\mathrm{D}_{30}{ }^{2} \mathrm{H}$ alometry is also performed by[37] for carbon sequestration of Kandelia obovata in Okinawa - Japan and [37] for aboveground biomass production of Rhizophora apiculata Blume in Sarawak mangrove forest. For carbon validation and verification purposes, it is recommended that mangrove carbon calculation use $\mathrm{D}_{30}{ }^{2} \mathrm{H}$ alometry because this calculation includes a tree high element in estimating vegetation carbon stocks.

Ecosystem carbon sequestration at 2-12 years and 2-30 years can be used as reference for proposing carbon credits Afforestation, Reforestation and Re-vegetation (ARR) scheme since the credit value is calculated since 2-year mangroves begin to sequester carbon. While carbon stocks and carbon sequestration at 12-30 years are used for certifying carbon credits Reducing Emissions from Defrorestation and Degradation (REDD) or ARR schemes when the carbon sequestration capabilities are calculated since the mangroves have grown from 12 year old.

The goal of carbon credit program is to prevent carbon emissions from permanently changing mangrove ecosystem cover to permanent non-mangrove vegetation. The program is expected to slow the rate of deforestation and degradation of existing mangrove ecosystems for long-term period in which [37] confirm that Rhizophora mangle mangrove species can continue growing until age around 250 years. Updating annual data is important being carried out in the study sites for monitoring an increase or decrease of mangrove carbon stocks and its sequestration in the future. It is also essential to build a better understanding on how the role of mangrove ecosystem in stabilizing $\mathrm{CO}_{2}$ in the atmosphere by conducting more study on how mangrove plants and soils absorb, store, and release carbon, also how these activities will affect the carbon cycle.

\section{Acknowledgements}

This paper is part of dissertation submitted by the first author to the Brawijaya University, Malang-Indonesia. We thank to the USAID - Indonesia Program who finances this research and to Livelihoods Fund in supporting long-term 
mangrove carbon project. We also thank to the Yagasu field team and volunteers from various university students in Medan that involve on the field data collection. We appreciate to the RISPA laboratory - Medan, IPB Soil Biotechnology - Bogor who allow us to use their laboratory for carbon fraction analysis. The special thanks are given to the research partners (Rahayu Subekti,
Melanton Haloho, Hasri Abdilah, Rangga Bayu Basuki, Dany Saragih and Ricky Stiawan) who assist in providing secondary data, mapping study sites, drawing illustrations and analysing statictical data. We also appreciate and thank to Prof. Zoelkifli Nasution and Nirmal Beura for proof-reading and critical review of this manuscript.

\section{Annexes}

\section{Annex 1. Study sites for biomass measurement and soil sample collection}

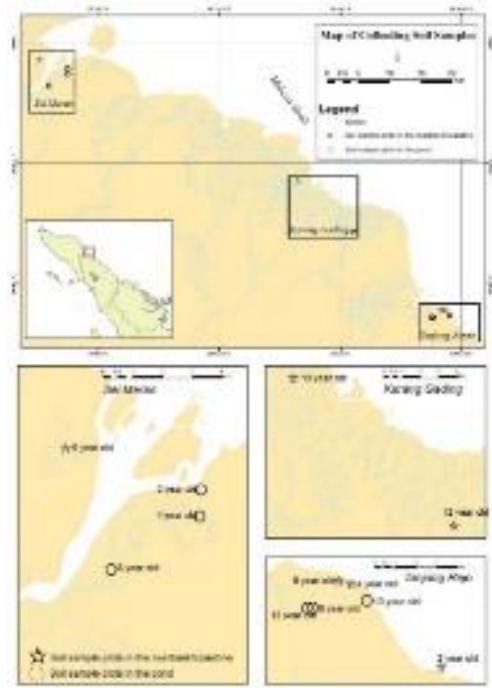

$$
\begin{aligned}
& 6 \text { years riverine (P. Siata) } 04^{\circ} 07^{\prime} 26.39 " \mathrm{~N} \text {; } \\
& 098^{\circ} 09^{\prime} 51.53^{\prime \prime} \mathrm{E}
\end{aligned}
$$

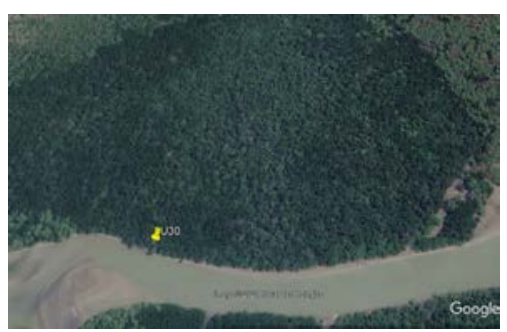

30 year riverine (J. halus) 035'ㄷ․39"N; 098³2'15.31"E

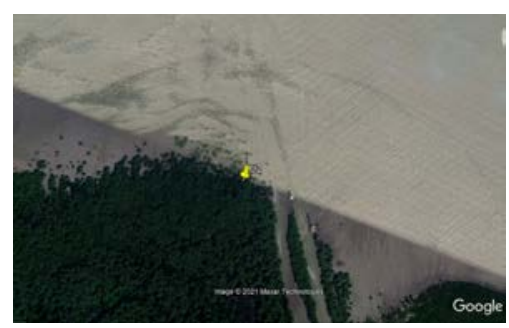

2 years riverine (Percut) 034'37.08"N; 09847'23.89"E
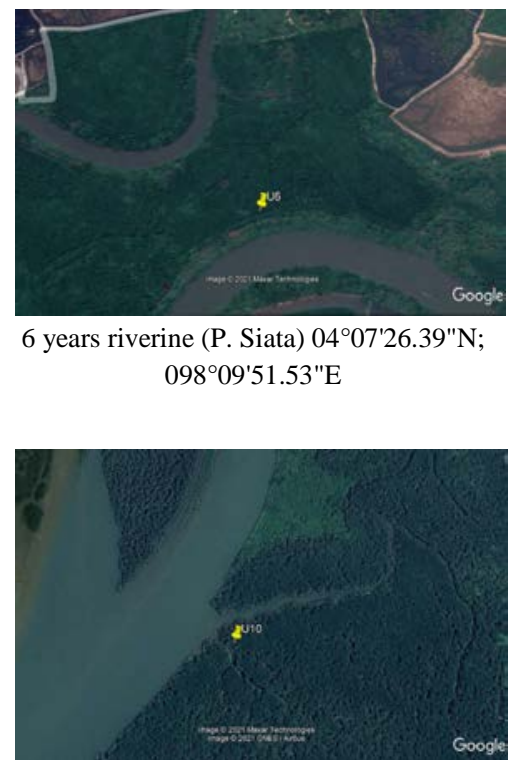

10 years riverine (J. halus) 035'58.39"N; 098³2'15.31"E

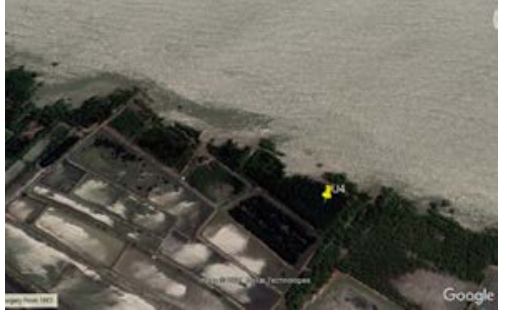

4 years riverine (T. Rejo) 034ㄴ'48.77"N; 09845'03.60"E

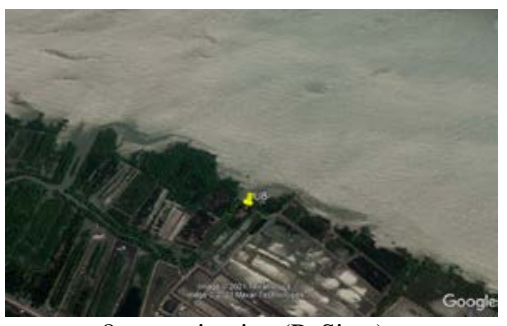

8 years riverine (P. Siata) 0345'53.32"N; 09844'44.89"E

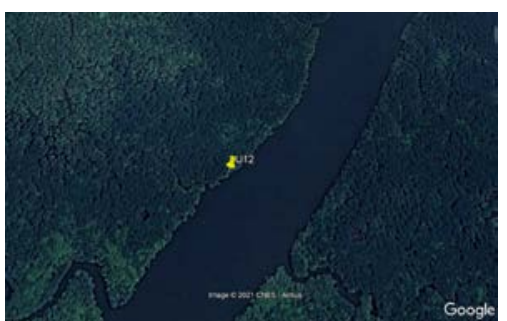

12 years riverine (P. Gading) 0352'36.47"N; 098³7'01.94"E 
Annex 2. Non-destructive transect and plot design for biomass measurement

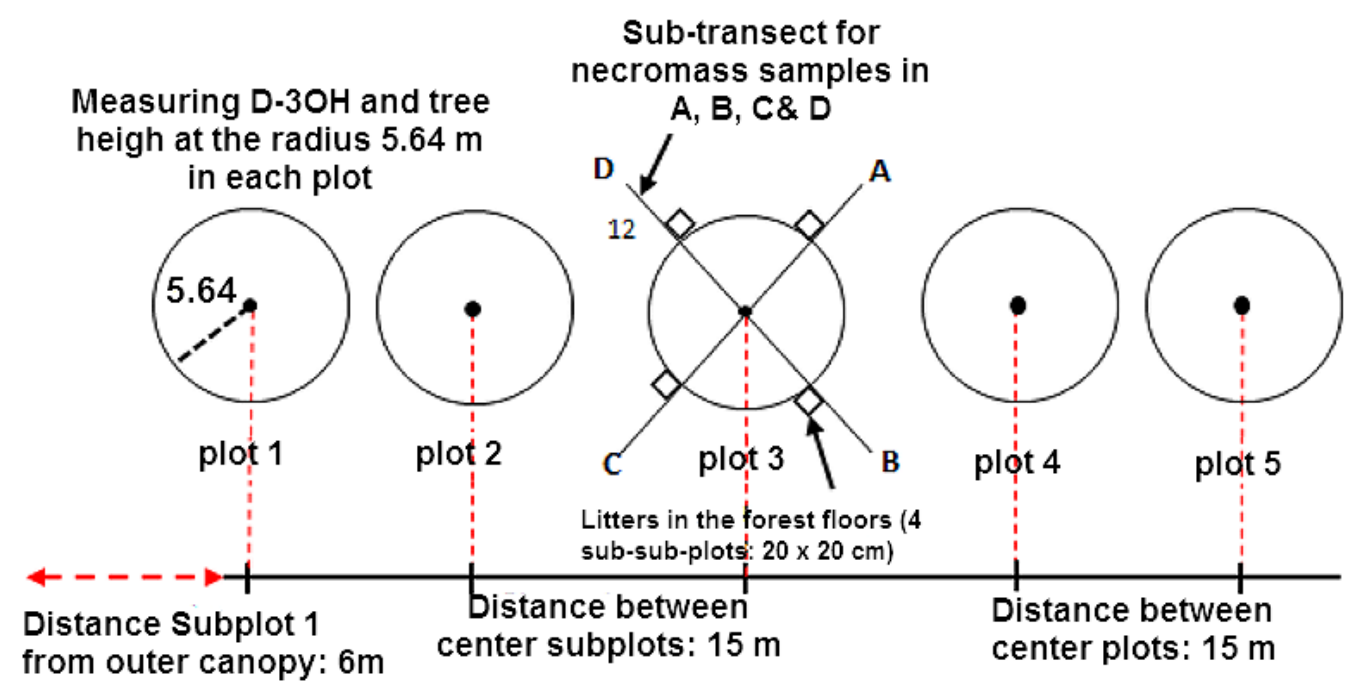

Annex 3. Transect and plot design in collecting soil samplings

\section{Collecting soil samples in each plot}

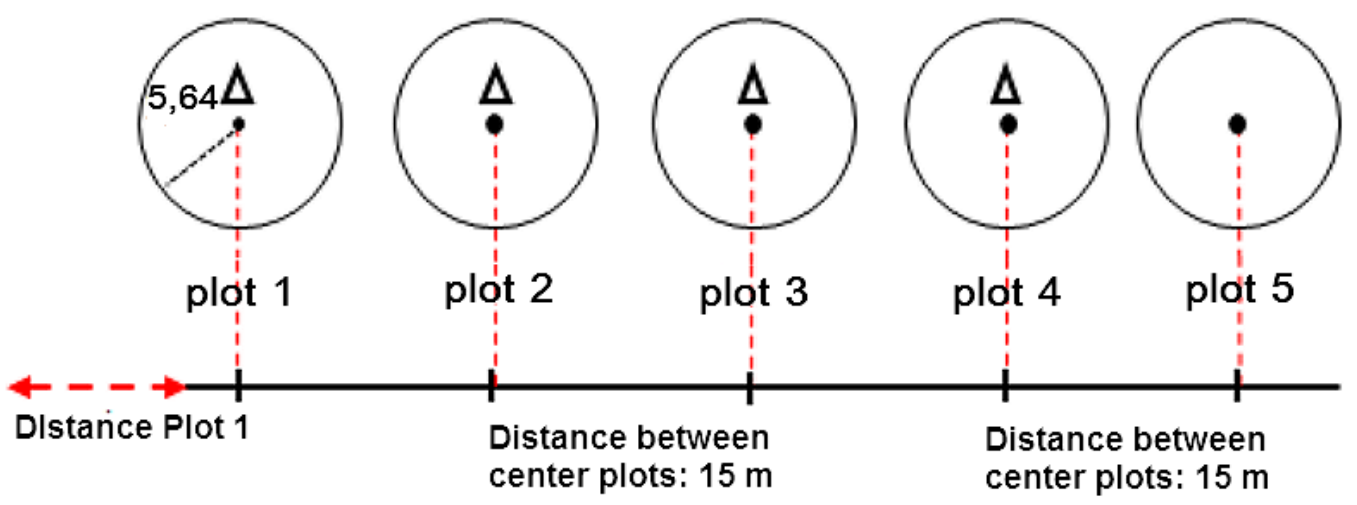

Annex 4. Two allometric references used for above- and belowground carbon stocks of 2 - 30 year restored mangroves:

The aboveground carbon based on diameter variable references:

- $\quad$. apiculata carbon estimation (AGC, $\mathrm{kg}$ ) from [38]:

- if $\mathrm{D}_{30}<5.1 \mathrm{~cm} ; \mathrm{AGC}=0.47 *\left(0.0000695 *\left(\left(\mathrm{D}_{30}\right) \wedge 2.64412\right) * \mathrm{WD}+\right.$

$10^{\wedge}\left(-1.8571+\left(2.1072 *\left(\operatorname{LOG}\left(\mathrm{D}_{30}\right)\right)\right)\right)+$

$0.0000695 *\left(\left(\mathrm{D}_{30}\right) \wedge 2.64412\right) * \mathrm{WD} * 0.101$

- if $\mathrm{D}_{30} 5.1-10.1 \mathrm{~cm}, \mathrm{AGC}=0.47 *\left(0.0000695 *\left(\left(\quad \mathrm{D}_{30}\right)^{\wedge} 2.64412\right) * \mathrm{WD}+\right.$

$10^{\wedge}\left(1.8571+\left(2.1072 *\left(\operatorname{LOG}\left(\mathrm{D}_{30}\right)\right)\right)\right)+$

$0.0000695 *\left(\left(D_{30}\right)^{\wedge} 2.64412\right) * W D * 0.204$

- if $\mathrm{D}_{30} 10.1-20.1 \mathrm{~cm}, \mathrm{AGC}=0.47 *\left(0.0000695 *\left(\left(\mathrm{D}_{30}\right)^{\wedge 2.64412}\right) * \mathrm{WD}+\right.$

$10 \wedge\left(-1.8571+\left(2.1072 *\left(\operatorname{LOG}\left(\mathrm{D}_{30}\right)\right)\right)\right)+0.0000695 *\left(\left(\mathrm{D}_{30}\right)^{\wedge} 2.64412\right) * \mathrm{WD} * 0.273$

- if $\mathrm{D}_{30}>20.1 \mathrm{~cm}, \mathrm{AGC}=0.47^{*}\left(0.0000695^{*}\left(\left(\mathrm{D}_{30}\right)^{\wedge} 2.64412\right)^{*} \mathrm{WD}+10^{\wedge}(-1.8571+\right.$

$\left.\left(2.1072 *\left(\mathrm{LOG}\left(\mathrm{D}_{30}\right)\right)\right)\right)+0.0000695 *\left(\left(\mathrm{D}_{30}\right) \wedge 2.64412\right) * \mathrm{WD} * 0.21$ 
- Aboveground carbon of other species using biomass references * $0.47(\mathrm{~kg})$

\begin{tabular}{|c|c|c|c|}
\hline \multirow[b]{2}{*}{ Species } & \multicolumn{2}{|c|}{ Aboveground biomass (AGB, kg) } & \multirow[b]{2}{*}{ Referensces } \\
\hline & Leaf biomass & Stem and branch biomass & \\
\hline B. sexangula & $10^{\wedge}\left(-1,1679+\left(1,4914 *\left(\operatorname{LOG}\left(\mathrm{D}_{30}\right)\right)\right)\right)$ & $\mathrm{WD} * 0,0000754 *\left(\mathrm{D}_{30} \wedge 2,5\right)$ & Kauffman\&Cole (2010) \\
\hline$X$. granatum & $10^{\wedge}\left(-1,1679+\left(1,4914^{*}\left(\operatorname{LOG}\left(\mathrm{D}_{30}\right)\right)\right)\right) * \mathrm{WD}$ & $\mathrm{WD} * 0,0000754 *\left(\mathrm{D}_{30} \wedge 2,5\right)$ & Kauffman\&Cole (2010) \\
\hline B. parviflora & $10^{\wedge}\left(-1,1679+\left(1,4914 *\left(\operatorname{LOG}\left(\mathrm{D}_{30}\right)\right)\right)\right) * \mathrm{WD}$ & $\mathrm{WD} * 0,0000754 *\left(\mathrm{D}_{30} \wedge 2,5\right)$ & Kauffman\&Cole (2010) \\
\hline S. alba & $10^{\wedge}\left(-1,1679+\left(1,4914^{*}\left(\operatorname{LOG}\left(\mathrm{D}_{30}\right)\right)\right)\right)$ & $\mathrm{WD} * 0,0003841 *\left(\mathrm{D}_{30} \wedge 2,1\right)$ & Kauffman\&Cole (2010) \\
\hline \multirow[t]{2}{*}{ R. mucronata } & $10^{\wedge}\left(-1,8571+\left(2,1072 *\left(\operatorname{LOG}\left(\mathrm{D}_{30}\right)\right)\right)\right)$ & $\mathrm{WD} * 0,0000695 *\left(\left(\mathrm{D}_{30}\right)^{\wedge} 2,64412\right)+$ & Kauffman\&Cole (2010) \\
\hline & $\begin{array}{c}\text { if }\left(\mathrm{D}_{30}<5,1\right), \\
\text { if }\left(\mathrm{D} 30>5, \mathrm{D}_{30}<10,1\right), \\
\text { if }\left(\mathrm{D} 30>10,1, \mathrm{D}_{30}<15,1\right), \\
\text { if }\left(\mathrm{D} 30>15, \mathrm{D}_{30}<20,1\right), \\
\text { jika }\left(\mathrm{D}_{30}>20,1\right)\end{array}$ & 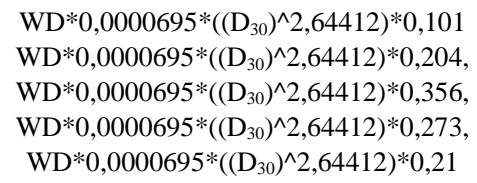 & Kauffman\&Cole (2010) \\
\hline E. agallocha & $10^{\wedge}\left(-1,1679+\left(1,4914 *\left(\operatorname{LOG}\left(D_{30}\right)\right)\right)\right)$ & $\mathrm{WD} * 0,0003841 *\left(\mathrm{D}_{30} \wedge 2,1\right)$ & Kauffman\&Cole (2010) \\
\hline S. caseolaris & $10^{\wedge}\left(-1,1679+\left(1,4914^{*}\left(\operatorname{LOG}\left(\mathrm{D}_{30}\right)\right)\right)\right)$ & $\mathrm{WD} * 0,0003841 *\left(\mathrm{D}_{30} \wedge 2,1\right)$ & Kauffman\&Cole (2010) \\
\hline A. marina & & $0,308 * \mathrm{D}_{30} \wedge 2,11$ & $\begin{array}{c}\text { Comley\&McGuinness } \\
\text { (2005) }\end{array}$ \\
\hline A. officinalis & & $0,308 * D_{30} \wedge 2,11$ & $\begin{array}{c}\text { Comley\&McGuinness } \\
\text { (2005) }\end{array}$ \\
\hline
\end{tabular}

- Belowground carbon of species using biomass references * 0.39 (kg)

\begin{tabular}{|c|c|c|}
\hline Species & Belowground biomass (BCG, kg) & References \\
\hline B. sexangula & $0.0188 *\left(\left(\mathrm{D}_{30} \wedge 2\right) *\left(\mathrm{D} 30 /\left(\left(0.025^{*} \mathrm{D}_{30}\right)+0.583\right)\right)\right)^{\wedge} 0.909$ & Tamai et al. (1986) \\
\hline X. granatum & $0.0188 *\left(\left(\mathrm{D}_{30} \wedge 2\right)^{*}\left(\mathrm{D} 30 /\left(\left(0.025^{*} \mathrm{D}_{30}\right)+0.583\right)\right)\right)^{\wedge} 0.909$ & Tamai et al. (1986) \\
\hline B. parviflora & $0.0188 *\left(\left(\mathrm{D}_{30} \wedge 2\right) *\left(\mathrm{D} 30 /\left(\left(0.025 * \mathrm{D}_{30}\right)+0.583\right)\right)\right)^{\wedge} 0.909$ & Tamai et al. (1986) \\
\hline S. alba & $0.199 * \mathrm{WD}^{\wedge} 0.899 * \mathrm{D}_{3} 0 \wedge 2.22$ & Komiyama et al. (2008) \\
\hline R. mucronata & $0.199 * \mathrm{WD}^{\wedge} 0.899 * \mathrm{D}_{30} \wedge 2.22$ & Komiyama et al. (2008) \\
\hline E. agallocha & $0.199 * \mathrm{WD}^{\wedge} 0.899 * \mathrm{D}_{30} \wedge 2.22$ & Komiyama et al. (2008) \\
\hline S. caseolaris & $0.199 * \mathrm{WD}^{\wedge} 0.899 * \mathrm{D}_{30} \wedge 2.22$ & Komiyama et al. (2008) \\
\hline A. marina & $1.28 * \mathrm{D}_{30} \wedge 1.17$ & Comley\&McGuinness (2005) \\
\hline A. officinalis & $1.28 * \mathrm{D}_{30} \wedge 1.17$ & Comley\&McGuinness (2005) \\
\hline
\end{tabular}

Biomass of all species (AGB, kg) based on quadratic diamater and tree height variables:

- $\mathrm{AGB}=0.0509 * \rho^{*}(\mathrm{D})^{2} * \mathrm{H}$ (Chave et al., 2005) for aboveground biomass (kg)

- $\mathrm{BGB},=0.39 * 0.199 * \mathrm{WD}^{\wedge} 0.899 * \mathrm{D}_{30} \wedge 2.22$ (Komiyama et al., 2008) for belowground biomass (kg).

Wood density of mangrove species: R. apiculata 1.047, S. alba 0.800, R. mucronata 1.027 E. agallocha 0.509, B. sexangula 0.917 , A. marina 0.817 , S. caseolaris 0.509 , A. officinalis 0.605 , X. granatum 0.567 and B. parviflora $0.760 \mathrm{~g}$ $\mathrm{cm}^{-3}[39]$.

\section{Annex 5. Average of stem diameter, tree height and their growth rate}

\begin{tabular}{ccccc|cccc}
\hline & \multicolumn{4}{c}{ Stem diameter $(\mathbf{c m})$} & \multicolumn{4}{c}{ Tree height (cm) } \\
\cline { 2 - 10 } Age (year) & Actual & $\begin{array}{c}\text { Actual } \\
\text { SDR }\end{array}$ & Scenario & $\begin{array}{c}\text { Scenario } \\
\text { SDR }\end{array}$ & Actual & $\begin{array}{c}\text { Actual } \\
\text { THR }\end{array}$ & $\begin{array}{c}\text { Scenario } \\
\text { Scenario } \\
\text { THR }\end{array}$ \\
\hline 2 & 2.8 & & 3.2 & & 133 & & 414.1 & \\
4 & 3.9 & 0.6 & 4.0 & 0.4 & 430 & 148.5 & 515.0 & 50.4 \\
6 & 4.2 & 0.2 & 4.8 & 0.4 & 591 & 80.5 & 615.9 & 50.4 \\
8 & 5.3 & 0.6 & 5.6 & 0.4 & 678 & 43.5 & 716.7 & 50.4 \\
10 & 7.4 & 1.1 & 6.4 & 0.4 & 1,129 & 225.5 & 817.6 & 50.4 \\
12 & 8.0 & 0.3 & 7.2 & 0.4 & 1,213 & 42.0 & 918.5 & 50.4 \\
30 & 10.6 & 0.1 & 14.6 & 0.4 & 1,650 & 24.3 & $1,826.3$ & 50.4 \\
\hline$(2-30)$ & 6.0 & 0.5 & 6.5 & 0.4 & 832.0 & 94.1 & 832.0 & 50.4 \\
\hline
\end{tabular}

$\mathrm{SDR}=$ Stem Diameter Rate $\left(\mathrm{cm} \mathrm{yr}^{-1}\right)$; THR = Tree Height Rate $\left(\mathrm{cm} \mathrm{yr}^{-1}\right)$ 
Annex 6. Average of basal area, shoot/root ratio and their growth rate

\begin{tabular}{ccccc|cccc}
\hline & \multicolumn{4}{c}{ Basal area $\left(\mathbf{m}^{2} \mathbf{h a}^{-1}\right)$} & \multicolumn{4}{c}{ Shoot/root ratio } \\
\cline { 2 - 9 } Age (year) & Actual & Actual BA & Scenario & $\begin{array}{c}\text { Scenario } \\
\text { BAR }\end{array}$ & Actual & $\begin{array}{c}\text { Actual } \\
\text { SRR }\end{array}$ & Scenario & $\begin{array}{c}\text { Scenario } \\
\text { SRRR }\end{array}$ \\
\hline 2 & 1.6 & & -6.7 & & 1.29 & & 186.67 \\
4 & 6.8 & 2.6 & 1.3 & 4.01 & 1.16 & -0.065 & 208.83 & 11.08 \\
6 & 6.7 & -0.05 & 9.4 & 4.01 & 1.05 & -0.055 & 230.99 & 11.08 \\
8 & 15.0 & 4.15 & 17.4 & 4.01 & 0.96 & -0.045 & 253.15 & 11.08 \\
10 & 21.7 & 3.35 & 25.4 & 4.01 & 0.85 & -0.055 & 275.31 & 11.08 \\
12 & 23.2 & 0.75 & 33.4 & 4.01 & 0.78 & -0.035 & 297.47 & 11.08 \\
30 & 110.8 & 4.87 & 105.6 & 4.01 & 0.74 & -0.002 & 496.91 & 11.08 \\
\hline$(2-30)$ & 26.54 & 2.61 & 26.54 & 4.01 & 0.98 & -0.043 & 278.48 & 11.08 \\
\hline
\end{tabular}

BAR = Basal Area Rate $\left(\mathrm{m}^{2} \mathrm{ha}^{-1} \mathrm{yr}^{-1}\right)$; SRRR = Shoot/Root Ratio Rate

Annex 7. Above- and belowground vegetation carbon stocks of restored mangroves using two different allometries

\begin{tabular}{|c|c|c|c|c|c|c|c|c|c|c|c|c|}
\hline \multirow{3}{*}{ Tree age } & \multicolumn{6}{|c|}{ Diameter allometry } & \multicolumn{6}{|c|}{ Quadratic diameter - tree heigh allometry } \\
\hline & \multicolumn{2}{|c|}{$\begin{array}{c}\text { BGC (MgC } \\
\left.\text { ha }^{-1}\right)\end{array}$} & \multicolumn{2}{|c|}{$\begin{array}{c}\text { AGC (MgC } \\
\left.\text { ha }^{-1}\right)\end{array}$} & \multicolumn{2}{|c|}{ Total (MgC ha-1) } & \multicolumn{2}{|c|}{$\begin{array}{c}\text { BGC (MgC } \\
\left.\text { ha }^{-1}\right)\end{array}$} & \multicolumn{2}{|c|}{ AGC (MgC ha-1) } & \multicolumn{2}{|c|}{ Total $\left(\mathrm{MgC} \mathrm{ha}^{-1}\right)$} \\
\hline & $\mathbf{x}$ & \pm sd & $\mathbf{x}$ & \pm sd & $\mathbf{X}$ & \pm sd & $\mathbf{X}$ & \pm sd & $\mathbf{X}$ & \pm sd & $\mathbf{X}$ & \pm sd \\
\hline 2 years & 2.0 & \pm 0.6 & 1.7 & \pm 0.6 & 3.7 & \pm 1.2 & 2.0 & \pm 0.6 & 0.9 & \pm 0.3 & 2.9 & \pm 0.9 \\
\hline 4 years & 10.1 & \pm 4.2 & 10.5 & \pm 5.3 & 20.6 & \pm 9.4 & 10.1 & \pm 4.2 & 11.3 & \pm 5.1 & 21.4 & \pm 9.2 \\
\hline 6 years & 9.5 & \pm 3.4 & 10.1 & \pm 3.9 & 19.6 & \pm 7.3 & 9.5 & \pm 3.4 & 12.6 & \pm 4.6 & 22.2 & \pm 8.0 \\
\hline 8 years & 22.6 & \pm 4.1 & 26.6 & \pm 3.7 & 49.2 & \pm 7.7 & 22.6 & \pm 4.1 & 33.6 & \pm 9.1 & 56.2 & \pm 13.2 \\
\hline 10 years & 33.6 & \pm 7.1 & 50.1 & \pm 10.8 & 83.8 & \pm 17.8 & 33.6 & \pm 7.1 & 81.3 & \pm 21.7 & 115.0 & \pm 28.7 \\
\hline 12 years & 34.0 & \pm 2.8 & 54.7 & \pm 3.8 & 88.7 & \pm 6.6 & 34.0 & \pm 2.8 & 88.8 & \pm 8.1 & 122.7 & \pm 10.8 \\
\hline 30 years & 44.4 & \pm 21.9 & 92.4 & \pm 54.2 & 136.8 & \pm 75.9 & 44.4 & \pm 21.9 & 143.1 & \pm 75.8 & 187.4 & \pm 97.6 \\
\hline $\begin{array}{r}(2-30 \\
\text { years })\end{array}$ & 22.3 & \pm 6.3 & 35.2 & \pm 11.8 & 57.5 & \pm 18.0 & 22.3 & \pm 6.3 & 53.1 & \pm 22.6 & 75.4 & \pm 29.7 \\
\hline $\begin{array}{l}(2-12 \\
\text { years })\end{array}$ & 18.6 & \pm 3.7 & 25.6 & \pm 4.7 & 44.3 & \pm 8.3 & 18.6 & \pm 3.7 & 38.1 & \pm 6.8 & 56.7 & \pm 11.3 \\
\hline $\begin{array}{l}(12-30 \\
\text { years })\end{array}$ & 39.2 & \pm 12.4 & 73.6 & \pm 29.0 & 112.8 & \pm 41.3 & 39.2 & \pm 12.4 & 116.0 & \pm 36.0 & 155.1 & \pm 54.0 \\
\hline
\end{tabular}

$\mathrm{X}=$ average value $; \mathrm{sd}=$ standard deviation; $\mathrm{SL}=$ Significant Level; NS = Not Significant; * = Significant at $\alpha 5 \%$ ** = Significant at $\alpha 1 \%$; n-plot $=35$

\section{Annex 8. Average soil density of restored mangrove plots}

\begin{tabular}{|c|c|c|c|c|c|c|c|c|c|c|c|c|c|c|}
\hline \multirow{3}{*}{$\begin{array}{l}\text { Age } \\
\text { sites }\end{array}$} & \multirow{2}{*}{\multicolumn{2}{|c|}{$\begin{array}{c}\text { Maximum } \\
\text { soil depth (cm) }\end{array}$}} & \multicolumn{12}{|c|}{ Average soil density $\left(\mathrm{g} \mathrm{cm}^{-3}\right)$} \\
\hline & & & \multicolumn{2}{|c|}{$\begin{array}{l}\text { Average all } \\
\text { depth }\end{array}$} & \multicolumn{2}{|c|}{ 0-15 cm depth } & \multicolumn{2}{|c|}{$15-30 \mathrm{~cm}$ depth } & \multicolumn{2}{|c|}{$30-50 \mathrm{~cm}$ depth } & \multicolumn{2}{|c|}{$\begin{array}{c}50-100 \mathrm{~cm} \\
\text { depth }\end{array}$} & \multicolumn{2}{|c|}{$\begin{array}{c}100-200 \mathrm{~cm} \\
\text { depth }\end{array}$} \\
\hline & $\mathbf{X}$ & \pm sd & $\mathbf{X}$ & \pm sd & $\mathbf{X}$ & \pm sd & $\mathbf{X}$ & \pm sd & $\mathbf{X}$ & \pm sd & $\mathbf{X}$ & \pm sd & $\mathbf{X}$ & \pm sd \\
\hline 2 years & $300 \mathrm{a}$ & \pm 0 & $1.07 \mathrm{a}$ & \pm 0.23 & $1.02 \mathrm{a}$ & \pm 0.28 & $0.94 \mathrm{ab}$ & \pm 0.11 & 1.08 a & \pm 0.35 & 1.17 a & \pm 0.30 & 1.15 a & \pm 0.27 \\
\hline 4 years & 267 c & \pm 13 & $0.76 \mathrm{c}$ & \pm 0.09 & 0.79 a & \pm 0.21 & $0.82 \mathrm{bc}$ & \pm 0.18 & $0.80 \mathrm{bc}$ & \pm 0.14 & 0.72 c & \pm 0.10 & $0.67 \mathrm{~d}$ & \pm 0.16 \\
\hline 6 years & $282 \mathrm{~b}$ & \pm 9 & $0.80 \mathrm{bc}$ & \pm 0.09 & $0.82 \mathrm{a}$ & \pm 0.12 & $0.81 \mathrm{bc}$ & \pm 0.11 & $0.76 \mathrm{c}$ & \pm 0.11 & $0.77 \mathrm{bc}$ & \pm 0.17 & $\begin{array}{l}0.84 \\
\text { bcd }\end{array}$ & \pm 0.16 \\
\hline 8 years & 299 a & \pm 3 & $0.77 \mathrm{bc}$ & \pm 0.06 & 0.83 a & \pm 0.11 & 0.75 c & \pm 0.14 & $0.78 \mathrm{c}$ & \pm 0.14 & $0.71 \mathrm{c}$ & \pm 0.09 & $0.79 \mathrm{~cd}$ & \pm 0.18 \\
\hline $\begin{array}{c}10 \\
\text { years }\end{array}$ & $300 \mathrm{a}$ & \pm 0 & $\begin{array}{c}0.90 \\
\text { abc }\end{array}$ & \pm 0.03 & $1.00 \mathrm{a}$ & \pm 0.11 & $0.95 \mathrm{ab}$ & \pm 0.03 & $\begin{array}{c}0.88 \\
\text { abc }\end{array}$ & \pm 0.09 & 0.84 bc & \pm 0.06 & $\begin{array}{l}0.85 \\
\text { abcd }\end{array}$ & \pm 0.09 \\
\hline $\begin{array}{c}12 \\
\text { years }\end{array}$ & 295 a & \pm 7 & $1.03 \mathrm{a}$ & \pm 0.05 & $1.02 \mathrm{a}$ & \pm 0.10 & $1.03 \mathrm{a}$ & \pm 0.14 & $1.00 \mathrm{ab}$ & \pm 0.10 & $1.00 \mathrm{ab}$ & \pm 0.11 & $1.12 \mathrm{ab}$ & \pm 0.14 \\
\hline $\begin{array}{c}30 \\
\text { years }\end{array}$ & 299 a & \pm 2 & $\begin{array}{c}0.95 \\
a b c\end{array}$ & \pm 0.03 & $0.96 \mathrm{a}$ & \pm 0.07 & $0.92 \mathrm{ab}$ & \pm 0.04 & $0.97 \mathrm{~b}$ & \pm 0.14 & $0.93 \mathrm{~b}$ & \pm 0.05 & $0.99 \mathrm{~b}$ & \pm 0.15 \\
\hline SL & $* *$ & & $* *$ & & NS & & $*$ & & $*$ & & $* *$ & & $*$ & \\
\hline
\end{tabular}

$\mathrm{X}=$ average value $; \mathrm{sd}=$ standard deviation; $\mathrm{SL}=$ Significant Level; NS = Not Significant; * = Significant at $\alpha 5 \%$;* = Significant at $\alpha 1 \%$; n-plot $=35$ 
Annex 9. Average soil C-content of restored mangrove plots

\begin{tabular}{|c|c|c|c|c|c|c|c|c|c|c|c|c|}
\hline \multirow[b]{3}{*}{$\begin{array}{l}\text { Age } \\
\text { sites }\end{array}$} & \multicolumn{12}{|c|}{ Average soil C-content (\%) } \\
\hline & \multicolumn{2}{|c|}{ Average all depth } & \multicolumn{2}{|c|}{ 0-15 cm depth } & \multicolumn{2}{|c|}{ 15-30 cm depth } & \multicolumn{2}{|c|}{$30-50$ cm depth } & \multicolumn{2}{|c|}{$50-100 \mathrm{~cm}$ depth } & \multicolumn{2}{|c|}{$100-200 \mathrm{~cm}$ depth } \\
\hline & $\mathbf{X}$ & \pm sd & $\mathbf{X}$ & \pm sd & $\mathbf{X}$ & \pm sd & $\mathbf{X}$ & \pm sd & $\mathbf{X}$ & \pm sd & $\mathbf{X}$ & \pm sd \\
\hline 2 years & $1.82 \mathrm{~d}$ & \pm 0.30 & $2.33 \mathrm{~b}$ & \pm 0.47 & $2.14 \mathrm{c}$ & \pm 0.45 & $1.96 \mathrm{~b}$ & \pm 0.55 & $1.80 \mathrm{c}$ & \pm 0.54 & 0.89 c & \pm 0.32 \\
\hline 4 years & $4.48 \mathrm{bcd}$ & \pm 0.40 & $3.03 \mathrm{~b}$ & \pm 0.63 & $4.62 \mathrm{bc}$ & \pm 2.32 & $6.00 \mathrm{~b}$ & \pm 1.43 & $4.43 \mathrm{bc}$ & \pm 0.83 & $4.33 \mathrm{bc}$ & \pm 1.48 \\
\hline 6 years & 13.26 a & \pm 3.73 & 10.98 a & \pm 5.80 & $12.05 \mathrm{a}$ & \pm 3.75 & 13.23 a & \pm 7.16 & $16.71 \mathrm{a}$ & \pm 4.07 & 13.36 a & \pm 6.10 \\
\hline 8 years & 4.98 bc & \pm 0.86 & $5.47 \mathrm{~b}$ & \pm 0.83 & $5.48 \mathrm{~b}$ & \pm 0.58 & $4.94 \mathrm{~b}$ & \pm 1.38 & $4.49 \mathrm{bc}$ & \pm 1.75 & 4.52 bc & \pm 0.41 \\
\hline $\begin{array}{c}10 \\
\text { years }\end{array}$ & 3.03 cd & \pm 0.57 & $2.88 \mathrm{~b}$ & \pm 0.44 & 2.57 bc & \pm 0.52 & $3.07 \mathrm{~b}$ & \pm 0.87 & $2.73 \mathrm{c}$ & \pm 1.04 & 3.88 bc & \pm 0.98 \\
\hline $\begin{array}{c}12 \\
\text { years }\end{array}$ & $5.90 \mathrm{~b}$ & \pm 1.08 & $4.37 \mathrm{~b}$ & \pm 0.51 & $4.27 \mathrm{bc}$ & \pm 0.56 & $5.03 \mathrm{~b}$ & \pm 0.98 & $7.29 \mathrm{~b}$ & \pm 3.35 & $8.54 \mathrm{ab}$ & \pm 4.05 \\
\hline $\begin{array}{c}30 \\
\text { years }\end{array}$ & $3.80 \mathrm{c}$ & \pm 0.57 & $3.89 \mathrm{~b}$ & \pm 0.82 & $3.10 \mathrm{bc}$ & \pm 0.82 & $3.81 \mathrm{~b}$ & \pm 0.76 & 4.26 bc & \pm 1.41 & 3.96 bc & \pm 1.39 \\
\hline SL & $* *$ & & $* *$ & & $* *$ & & $* *$ & & $* *$ & & $* *$ & \\
\hline
\end{tabular}

$\mathrm{X}=$ average value $; \mathrm{sd}=$ standard deviation; $\mathrm{SL}=$ Significant Level; NS = Not Significant; $*=$ Significant at $\alpha 5 \%$;* = Significant at $\alpha 1 \%$; n-plot $=35$

Annex 10. Soil carbon stocks of restored mangrove plots

\begin{tabular}{|c|c|c|c|c|c|c|c|c|c|c|c|c|}
\hline \multirow[b]{3}{*}{ Age sites } & \multicolumn{12}{|c|}{ Soil carbon stocks $\left(\mathrm{MgC} \mathrm{ha}^{-1}\right)$} \\
\hline & \multicolumn{2}{|c|}{ Total all depth } & \multicolumn{2}{|c|}{ 0-15 cm depth } & \multicolumn{2}{|c|}{$15-30 \mathrm{~cm}$ depth } & \multicolumn{2}{|c|}{ 30-50 cm depth } & \multicolumn{2}{|c|}{ 50-100 cm depth } & \multicolumn{2}{|c|}{$100-200 \mathrm{~cm}$ depth } \\
\hline & $\mathbf{X}$ & \pm sd & $\mathbf{X}$ & \pm sd & $\mathbf{X}$ & \pm sd & $\mathbf{X}$ & \pm sd & $\mathbf{X}$ & \pm sd & $\mathbf{X}$ & \pm sd \\
\hline 2 years & $80.1 \mathrm{~b}$ & \pm 10.0 & $6.9 \mathrm{~b}$ & \pm 1.0 & $6.0 \mathrm{c}$ & \pm 1.2 & $7.8 \mathrm{~b}$ & \pm 0.8 & $20.0 \mathrm{c}$ & \pm 4.6 & $39.3 \mathrm{~b}$ & \pm 10.0 \\
\hline 4 years & $167.2 \mathrm{~b}$ & \pm 36.8 & $8.0 \mathrm{~b}$ & \pm 4.4 & $11.6 \mathrm{bc}$ & \pm 7.4 & $19.0 \mathrm{~b}$ & \pm 4.9 & 31.7 c & \pm 6.5 & $97.0 \mathrm{~b}$ & \pm 37.3 \\
\hline 6 years & 618.0 a & \pm 180.9 & $26.4 \mathrm{a}$ & \pm 14.5 & $28.4 \mathrm{a}$ & \pm 7.5 & $40.8 \mathrm{a}$ & \pm 25.4 & $124.9 \mathrm{a}$ & \pm 21.8 & 397.5 a & \pm 179.0 \\
\hline 8 years & $207.8 \mathrm{~b}$ & \pm 47.5 & $14.5 \mathrm{~b}$ & \pm 4.5 & $12.2 \mathrm{bc}$ & \pm 1.5 & $14.9 \mathrm{~b}$ & \pm 3.3 & $32.4 \mathrm{c}$ & \pm 14.9 & $133.9 \mathrm{~b}$ & \pm 54.9 \\
\hline 10 years & $182.6 \mathrm{~b}$ & \pm 38.8 & $8.6 \mathrm{~b}$ & \pm 1.9 & 7.4 bc & \pm 1.6 & $10.9 \mathrm{~b}$ & \pm 3.5 & $23.1 \mathrm{c}$ & \pm 9.3 & $132.5 \mathrm{~b}$ & \pm 38.2 \\
\hline 12 years & $511.5 \mathrm{a}$ & \pm 189.0 & $13.3 \mathrm{~b}$ & \pm 2.3 & $13.8 \mathrm{~b}$ & \pm 2.9 & $20.3 \mathrm{~b}$ & \pm 4.9 & $74.5 \mathrm{~b}$ & \pm 40.0 & 389.7 a & \pm 184.3 \\
\hline 30 years & $231.5 \mathrm{~b}$ & \pm 67.9 & $11.2 \mathrm{~b}$ & \pm 2.7 & 8.6 bc & \pm 2.5 & $14.6 \mathrm{~b}$ & \pm 2.7 & 39.7 c & \pm 14.2 & $157.3 \mathrm{~b}$ & \pm 67.8 \\
\hline SL & $* *$ & & $* *$ & & $* *$ & & $* *$ & & $* *$ & & $* *$ & \\
\hline $\begin{array}{c}(2-30 \\
\text { years })\end{array}$ & 285.5 & \pm 81.6 & 12.7 & \pm 4.5 & 12.6 & \pm 3.5 & 18.3 & \pm 6.5 & 49.5 & \pm 15.9 & 192.5 & \pm 81.6 \\
\hline $\begin{array}{l}(2-12 \\
\text { years })\end{array}$ & 294.5 & \pm 83.8 & 13.0 & \pm 4.8 & 13.2 & \pm 3.7 & 19.0 & \pm 7.1 & 51.1 & \pm 16.2 & 198.3 & \pm 84.0 \\
\hline $\begin{array}{l}(12-30 \\
\text { years) }\end{array}$ & 371.5 & \pm 128.4 & 12.25 & \pm 2.5 & 11.2 & \pm 2.7 & 17.45 & \pm 3.8 & 57.1 & \pm 27.1 & 273.5 & \pm 126.1 \\
\hline
\end{tabular}

$\mathrm{X}=$ average value $; \mathrm{sd}=$ standard deviation; $\mathrm{SL}=$ Significant Level; NS = Not Significant; * = Significant at $\alpha$ 5\%; ** = Significant at $\alpha 1 \%$; (2-12 years) $=$ average carbon stocks of $2-12$ year old; $n$-plot $=35$

\section{Annex 11. Physical-chemical factors of sediments at restored mangrove plots}

\begin{tabular}{|c|c|c|c|c|c|c|c|c|c|c|c|c|c|c|c|}
\hline \multirow{2}{*}{$\begin{array}{l}\text { Tree } \\
\text { plots }\end{array}$} & \multicolumn{2}{|c|}{$\begin{array}{c}\text { Soil redox } \\
(\mathrm{mV})\end{array}$} & \multicolumn{2}{|c|}{ Soil temp. $\left({ }^{\circ} \mathrm{C}\right)$} & \multicolumn{2}{|c|}{ Salinity (ppt) } & \multicolumn{2}{|c|}{ Soil pH } & \multicolumn{2}{|c|}{ Sand (\%) } & \multicolumn{2}{|c|}{ Silt (\%) } & \multicolumn{2}{|c|}{ Clay(\%) } & \multirow[b]{2}{*}{$\begin{array}{c}\text { Soil } \\
\text { texture }\end{array}$} \\
\hline & $\mathbf{X}$ & $\pm \mathbf{s d}$ & $\mathbf{X}$ & $\pm \mathbf{s d}$ & $\mathbf{X}$ & \pm sd & $\mathbf{X}$ & \pm sd & $\mathbf{X}$ & $\begin{array}{c} \pm \\
\text { sd }\end{array}$ & $\mathbf{X}$ & $\begin{array}{c} \pm \\
\text { sd }\end{array}$ & $\mathbf{X}$ & $\begin{array}{c} \pm \\
\text { sd }\end{array}$ & \\
\hline $\begin{array}{c}2 \\
\text { years }\end{array}$ & 22.9 a & \pm 2.2 & 32.9ab & \pm 3.1 & $27.4 \mathrm{~d}$ & \pm 0.9 & $7.2 \mathrm{a}$ & \pm 0.1 & 69 bc & \pm 6 & $22 \mathrm{ab}$ & \pm 5 & 9 bc & \pm 2 & $\begin{array}{c}\text { Sandy } \\
\text { loam }\end{array}$ \\
\hline $\begin{array}{c}4 \\
\text { years }\end{array}$ & $7.8 \mathrm{~b}$ & \pm 0.5 & $36.5 \mathrm{a}$ & \pm 5.4 & $33.8 \mathrm{~b}$ & \pm 1.5 & 6.9abc & \pm 0.2 & 71abc & \pm 2 & 17 bc & \pm 1 & $12 \mathrm{~b}$ & \pm 1 & $\begin{array}{c}\text { Sandy } \\
\text { loam }\end{array}$ \\
\hline $\begin{array}{c}6 \\
\text { years }\end{array}$ & $26.5 \mathrm{a}$ & \pm 10.0 & 28.2bc & \pm 1.1 & $15.8 \mathrm{e}$ & \pm 1.9 & 6.9abc & \pm 0.2 & $76 \mathrm{a}$ & \pm 7 & $14 \mathrm{c}$ & \pm 5 & $10 \mathrm{bc}$ & \pm 3 & $\begin{array}{c}\text { Loamy } \\
\text { sand }\end{array}$ \\
\hline $\begin{array}{c}8 \\
\text { years }\end{array}$ & $20.2 \mathrm{a}$ & \pm 3.4 & $30.9 b c$ & \pm 4.1 & $37.0 \mathrm{a}$ & \pm 1.0 & $6.7 \mathrm{c}$ & \pm 0.4 & 70abc & \pm 6 & $13 \mathrm{c}$ & \pm 2 & 17 a & \pm 5 & $\begin{array}{c}\text { Sandy } \\
\text { loam }\end{array}$ \\
\hline $\begin{array}{c}10 \\
\text { years }\end{array}$ & $25.8 \mathrm{a}$ & \pm 0.2 & 27.7 c & \pm 0.2 & $6.6 \mathrm{f}$ & \pm 1.4 & $6.8 \mathrm{bc}$ & \pm 0.1 & $66 \mathrm{c}$ & \pm 6 & $24 \mathrm{a}$ & \pm 5 & $10 \mathrm{bc}$ & \pm 1 & $\begin{array}{c}\text { Sandy } \\
\text { loam }\end{array}$ \\
\hline $\begin{array}{c}12 \\
\text { years }\end{array}$ & $21.9 \mathrm{a}$ & \pm 1.1 & 28.7bc & \pm 0.3 & $27.9 \mathrm{c}$ & \pm 0.5 & $6.8 \mathrm{abc}$ & \pm 0.4 & $75 \mathrm{ab}$ & \pm 5 & $18 a b c$ & \pm 4 & $7 \mathrm{c}$ & \pm 1 & $\begin{array}{c}\text { Loamy } \\
\text { sand }\end{array}$ \\
\hline $\begin{array}{c}30 \\
\text { years }\end{array}$ & $25.8 \mathrm{a}$ & \pm 2.8 & $27.1 \mathrm{c}$ & \pm 0.6 & $17.9 \mathrm{e}$ & \pm 0.5 & $7.2 \mathrm{a}$ & \pm 0.2 & 77abc & \pm 4 & $14 \mathrm{c}$ & \pm 3 & 9 bc & \pm 1 & $\begin{array}{c}\text { Sandy } \\
\text { loam }\end{array}$ \\
\hline SL & NS & & $* *$ & & $* *$ & & $* *$ & & $* *$ & & $* *$ & & $* *$ & & \\
\hline
\end{tabular}

$\mathrm{X}=$ average value $; \mathrm{sd}=$ standard deviation; $\mathrm{SL}=$ Significant Level; NS $=$ Not Significant $*=$ Significant at $\alpha 5 \% ; * *$ Significant at $\alpha 1 \%$; n-plot = 35; 
Annex 12. Carbon stocks of necromass and litters (MgC ha-1)

\begin{tabular}{|c|c|c|c|c|c|c|}
\hline \multirow[b]{2}{*}{ Tree age } & \multicolumn{2}{|c|}{ Necromass } & \multicolumn{2}{|c|}{ Litters } & \multicolumn{2}{|c|}{ Total } \\
\hline & $\mathbf{X}$ & $\pm s d$ & $\mathbf{X}$ & \pm sd & $\mathbf{X}$ & \pm sd \\
\hline 2 years & & & 1.03 & \pm 0.13 & 1.03 & \pm 0.13 \\
\hline 4 years & 0.47 & \pm 0.27 & 0.73 & \pm 0.56 & 1.20 & \pm 0.83 \\
\hline 6 years & 0.51 & \pm 0.30 & 1.26 & \pm 0.18 & 1.77 & \pm 0.48 \\
\hline 8 years & 0.65 & \pm 0.21 & 0.74 & \pm 0.10 & 1.39 & \pm 0.31 \\
\hline 10 years & 0.28 & \pm 0.12 & 0.35 & \pm 0.09 & 0.63 & \pm 0.21 \\
\hline 12 years & 0.23 & \pm 0.12 & 0.38 & \pm 0.28 & 0.61 & \pm 0.4 \\
\hline 30 years & 0.32 & \pm 0.03 & 1.00 & \pm 0.28 & 1.32 & \pm 0.31 \\
\hline (2-30 years) & 0,41 & $\pm 0,10$ & 0,78 & $\pm 0,16$ & 1,14 & $\pm 0,23$ \\
\hline (2-12 years) & 0,43 & $\pm 0,08$ & 0,75 & $\pm 0,18$ & 1,11 & $\pm 0,25$ \\
\hline (12-30 years) & 0,28 & $\pm 0,06$ & 0,69 & $\pm 0,00$ & 0,97 & $\pm 0,06$ \\
\hline
\end{tabular}

$\mathrm{X}=$ mean $;$ sd = deviation standard; n-plot $=35$

Annex 13. Ecosystem carbon stocks (MgC ha $\left.{ }^{-1}\right)$ of restored mangroves

\begin{tabular}{ccccccccc}
\hline & \multicolumn{4}{c}{$\mathbf{D}_{\mathbf{3 0}}$ allometry } & \multicolumn{3}{c}{$\mathbf{D}_{\mathbf{3 0}}{ }^{2} \mathbf{H}$ allometry } \\
\cline { 2 - 9 } Tree age & SC & VC & DC & EC & SC & VC & DC & EC \\
\hline 2 years & 80.1 & 3.7 & 1.0 & 84.8 & 80.1 & 2.9 & 1.0 & 84.0 \\
4 years & 167.2 & 20.6 & 1.2 & 189.0 & 167.2 & 21.4 & 1.2 & 189.8 \\
6 years & 618.0 & 19.6 & 1.8 & 639.4 & 618.0 & 22.2 & 1.8 & 642.0 \\
8 years & 207.8 & 49.2 & 1.4 & 258.4 & 207.8 & 56.2 & 1.4 & 265.4 \\
10 years & 182.6 & 83.8 & 0.6 & 267.0 & 182.6 & 115 & 0.6 & 298.2 \\
12 years & 511.5 & 88.7 & 0.6 & 600.8 & 511.5 & 122.7 & 0.6 & 634.8 \\
30 years & 231.5 & 136.8 & 1.3 & 369.6 & 231.5 & 187.4 & 1.3 & 420.2 \\
\hline (2-30 years) & 285.5 & 57.5 & 1.1 & 344.1 & 285.5 & 75.4 & 1.1 & 362.0 \\
(2-12 years) & 294.5 & 44.3 & 1.1 & 339.9 & 294.5 & 56.7 & 1.1 & 352.3 \\
(12-30 years) & 371.5 & 112.8 & 1.0 & 485.3 & 371.5 & 155.1 & 1.0 & 527.6 \\
\hline
\end{tabular}

n-plot $=35$

Annex 14. Percentage soil carbon to the ecosystem carbon stocks

\begin{tabular}{cccccc}
\hline & & \multicolumn{2}{c}{$\mathbf{D}_{\mathbf{3 0}}$ allometry } & \multicolumn{2}{c}{$\mathbf{D}_{\mathbf{3 0}}{ }^{2} \mathbf{H}$ allometry } \\
\cline { 3 - 6 } Tree ages & $\mathbf{S C}$ & \% soil & $\mathbf{E C}$ & \% soil & EC \\
\hline 2 years & 80.1 & $95.6 \%$ & 84.8 & $96.9 \%$ & 84.0 \\
4 years & 167.2 & $89.0 \%$ & 189.0 & $89.6 \%$ & 189.8 \\
6 years & 618.0 & $96.9 \%$ & 639.4 & $96.8 \%$ & 642.0 \\
8 years & 207.8 & $80.9 \%$ & 258.4 & $80.2 \%$ & 265.4 \\
10 years & 182.6 & $68.5 \%$ & 267.0 & $63.8 \%$ & 298.2 \\
12 years & 511.5 & $85.2 \%$ & 600.8 & $82.4 \%$ & 634.8 \\
30 years & 231.5 & $62.9 \%$ & 369.6 & $57.9 \%$ & 420.2 \\
\hline (2-30 years) & 285.5 & $83.2 \%$ & 344.1 & $80.8 \%$ & 362.0 \\
(2-12 years) & 294.5 & $86.9 \%$ & 339.9 & $85.2 \%$ & 352.3 \\
(12-30 years) & 371.5 & $76.7 \%$ & 485.3 & $72.8 \%$ & 510.4 \\
\hline
\end{tabular}

SCS = Soil Carbon Stock (MgC ha-1); ECS = Ecosystem Carbon Stock; $\mathrm{n}$ plot = 35 
Annex 15. Vegetation carbon stocks $\left(\mathrm{MgC} \mathrm{ha}^{-1}\right)$ at ideal. actual and lost condition

\begin{tabular}{ccccccc}
\hline & \multicolumn{3}{c}{ Diameter References (DR) } & \multicolumn{2}{c}{ Diameter- Height Reference (DHR) } \\
\cline { 2 - 7 } Tree age & Ideal & Actual & Lost & Ideal & Actual & Lost \\
\hline 2 years & 3.8 & 3.7 & 0.1 & 3.0 & 2.9 & 0.1 \\
4 years & 20.6 & 20.6 & 0.0 & 21.4 & 21.4 & 0.0 \\
6 years & 19.6 & 19.6 & 0.0 & 22.2 & 22.2 & 0.0 \\
8 years & 49.5 & 49.2 & 0.3 & 56.5 & 56.2 & 0.3 \\
10 years & 87.6 & 83.8 & 3.9 & 118.4 & 115.0 & 3.4 \\
12 years & 96.0 & 88.7 & 7.3 & 128.8 & 122.7 & 6.1 \\
30 years & 137.1 & 136.8 & 0.3 & 187.6 & 187.4 & 0.2 \\
\hline (2-30 years) & 59.2 & 57.5 & 1.7 & 76.8 & 75.4 & 1.4 \\
\hline
\end{tabular}

n-plot $=35$

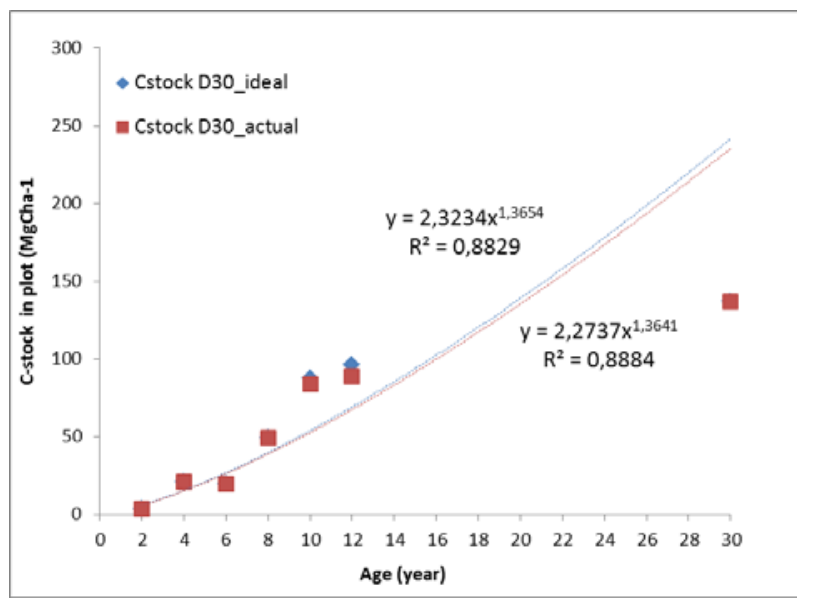

$\mathrm{D}_{30}$ allometry

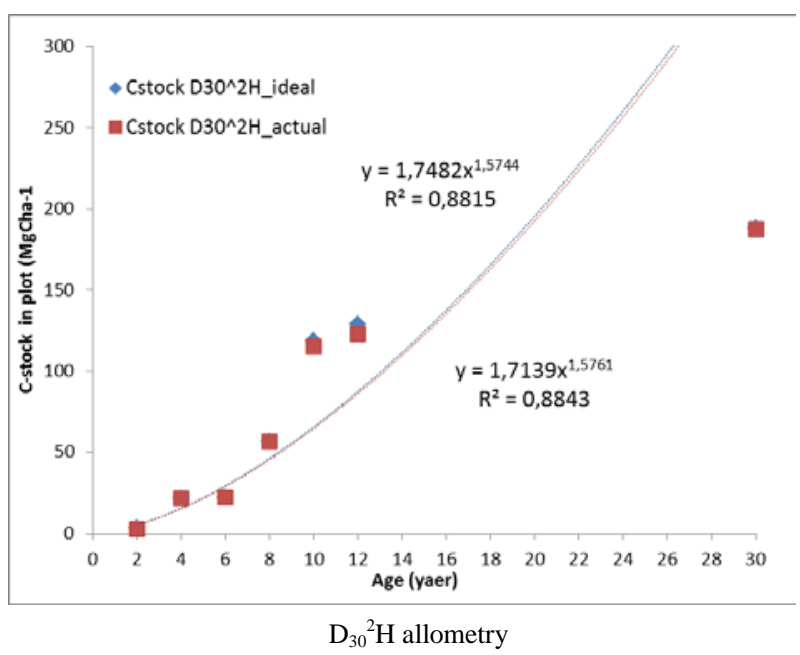

Annex 16. Regression of carbon stocks based on two allometries

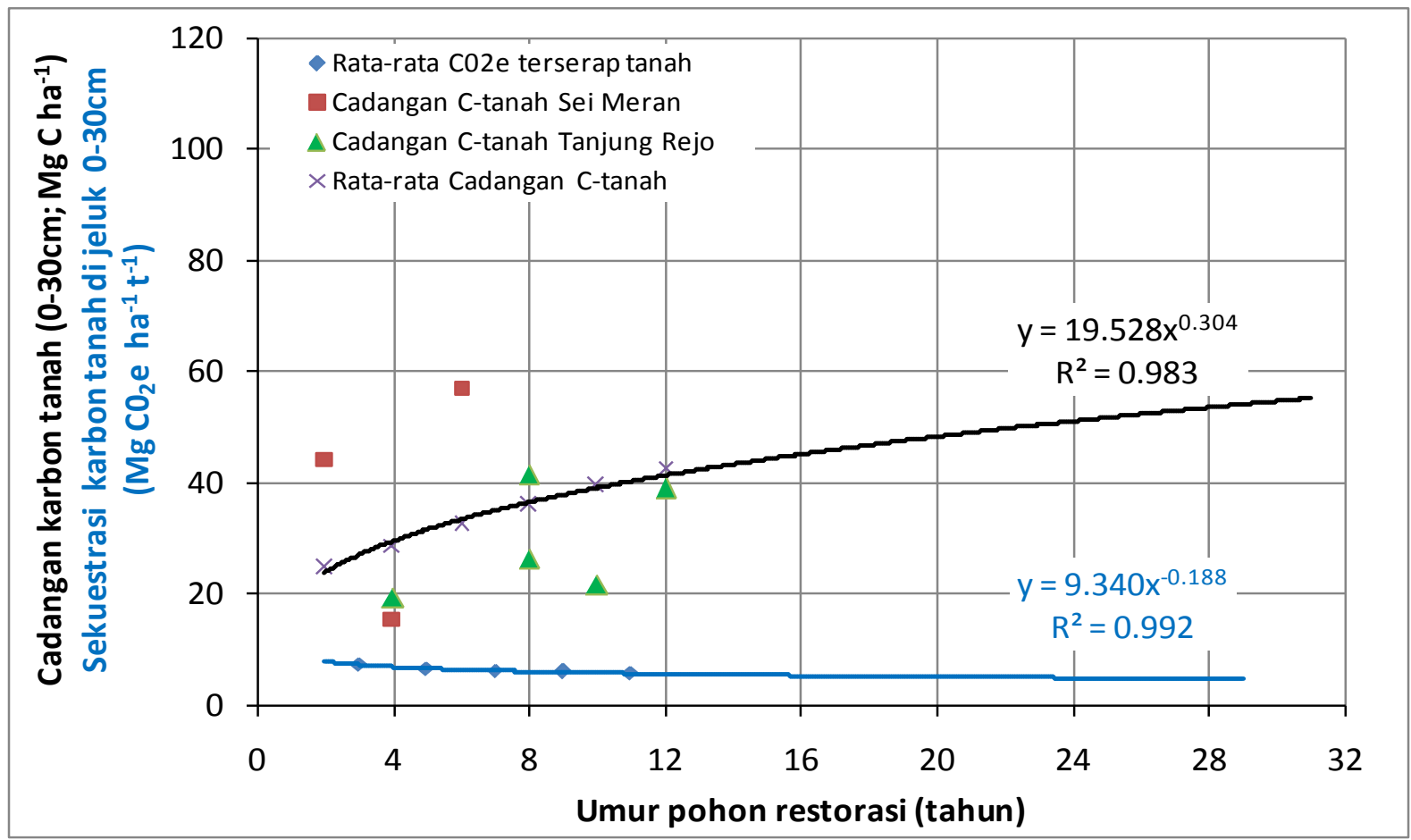

Figure 17. Estimation of soil carbon stock and its sequestration based on clustered plots at Sei Meran and Tanjung Rejo 
Table 18. Ecosystem carbon sequestration $\left(\mathrm{MgCO}_{2} \mathrm{e} \mathrm{ha}^{-1} \mathrm{yr}^{-1}\right)$

\begin{tabular}{ccccccc}
\hline & \multicolumn{3}{c}{$\mathbf{D}_{\mathbf{3 0}}$ allometry } & \multicolumn{3}{c}{$\mathbf{D}_{\mathbf{3 0}}{ }^{2} \mathbf{H}$ allometry } \\
\cline { 2 - 7 } Age range & $\mathbf{S C}$ & $\mathbf{V C}$ & Total & SC & VC & Total \\
\hline $2-4$ years & 6.6 & 17.1 & 23.7 & 6.6 & 18.7 & 25.3 \\
$4-6$ years & 6.6 & 20.7 & 27.3 & 6.6 & 25.2 & 31.8 \\
$6-8$ years & 6.6 & 23.4 & 30.0 & 6.6 & 30.6 & 37.2 \\
$8-12$ years & 6.6 & 25.6 & 32.2 & 6.6 & 35.4 & 42.0 \\
$10-12$ years & 6.6 & 27.6 & 34.2 & 6.6 & 39.7 & 46.3 \\
$12-30$ years & 6.6 & 34.7 & 41.3 & 6.6 & 57.2 & 63.8 \\
\hline (2-30 years) & 6.6 & 24.9 & 31.5 & 6.6 & 34.5 & 41.1 \\
(2-12 years) & 6.6 & 22.9 & 29.5 & 6.6 & 29.9 & 36.5 \\
(12-30 years) & 6.6 & 31.1 & 37.7 & 6.6 & 48.5 & 55.1 \\
\hline
\end{tabular}

$\mathrm{SC}=$ Soil Carbon; $\mathrm{VC}=$ Vegetation Carbon; $\mathrm{n}$-plot $=35$

\section{REFERENCES}

[1] Alavaisha, E. and M.M. Mangora. 2016. Carbon stocks in the small estuarine of Geza and Mtimbwani, Yanga, Tanzania. International Journal of Forestry Research, Vol 2016: 11 pages.

[2] Alongi, D.M., G. Wattayakorn, T. Ayaki, B.F. Clough, E. Wolanski and G.J. Brunskill. 2000. An Organic Carbon Budget for Mangrove-fringed Sawi Bay, Southern Thailand. Phuket Marine Biological Centre Special Publication. 22: 79-85.

[3] Alongi, D.M. 2009. Paradigm Shift in Mangrove Biology. Coastal Wetlands: An Integrated Ecosystem Approach: 615 -640 .

[4] Alongi, D.M. 2014. Carbon cycling and storage in mangrove forests. Annual Review of Marine Science, 6: 195 $-219$.

[5] Bouillon, S., Dahdouh-Guebas, F., Rao, A. S., Koedam, N., Dehairs, F., 2003. Sources of organic carbon in mangrove sediments: variability and possible ecological implications. Hydrobiologia, 495, 33-39.

[6] Bouillon, S. 2011. Carbon cycle: Storage beneath mangroves. News \& Views. Nature Geoscience, Vol 4.

[7] Breithaupt, J.L., J.M. Smoak, T.J. Smith III, C,J. Sanders and A. Hoare. 2012. Organic carbon burial rates in mangroves sediments: strengthening the global budget. Global Biogeochemical Cycles, Vol 26.

[8] Cebrian, J. 2002. Variability and control of carbon consumption, export and accumulation in marine communities. Limnology and Oceanography. 47: 11 - 22.

[9] Chandra, I.A., Seca, G., Abu Hena, M.K., 2011. Aboveground biomass production of Rhizophora apiculata Blume in Sarawak mangrove forest. American Journal of Agricultural and Biological Sciences 6 (4): 469-474.

[10] Chen, R. and Twilley, R.R., 1998. A gap dynamic model of mangrove forest development along gradients of soil salinity and nutrient resources. Journal of Ecology, 86:37-51.
[11] Chen, R. and Twilley, R.R., 1999. A simulation model of organic matter and nutrient accumulation in mangrove wetland soils. Biogeochemistry, 44 (1): 93-118.

[12] Chmura, G.L., S.C. Anisfeld, D.R. Cahoon and J.C. Lynch. (2003). Global carbon sequestration in tidal, saline wetland soils. Global Biogeochemical Cycles, 17(4): 111-121.

[13] Christensen, B., 1978. Biomass and productivity of Rhizophora apiculata B1 in a mangrove in Southern Thailand. Aquat. Bot. 4: 43-52.

[14] Cohen R., J. Kaino, J.A. Okello, J.O. Bosire, J.G. Kairo, M. Huxham, M. Mencuccini. 2013. Propagating uncertainty to estimates of above-ground biomass for Kenyan mangroves: A scaling procedure from tree to landscape level. Forest Ecology and Management 310: 968-982.

[15] Donato, D.C., Kauffman, J.B., Murdiyarso, D., Kurnianto, S., Stidham, M., Kanninen, M. 2011. Mangroves among the most carbon-rich forests in the tropics. Nature Geosiences 4: $293-297$.

[16] Duarte, C.M. and J. Cebrian. 1996. The Fate of Marine Autotropic Production.Limnology and Oceanography 41: 1758 - 1766.

[17] Eong, O.J., 1993. Mangroves - a carbon source and sink. Chemosphere, 27: 1097 - 1107.

[18] Fujimoto, K., A. Imaya, R. Tabuchi, S. Kuramoto, H. Utsugi and T. Murofushi. 1999. Belowground carbon storage of Micronesia mangrove forests. Ecological Research, Vol 14(4): 409-413.

[19] Furukawa, K., E. Wolanski \& H. Mueller. 1997. Currents and sediment transport in mangrove forests. Estuar. Coast. Shelf Sci. 44: 301-310.

[20] Hoque, A.T.M.R., S. Sharma and A. Hagihara. 2010. Carbon Acquisition of mangrove Kandelia obovate trees. Proc. Of International Conference on Environmental Aspects of Bangladesh (ICEAB10), Japan.

[21] IPCC. 2001. Climate Change 2001: The Scientific Basis. Contribution of Working Group I to the Third Assessment Report of the Intergovernmental Panel on Climate Change. Cambridge, UK. Cambridge University Press: 881 pp.

[22] IPCC, 2014. Supplement to the 2006 IPCC Guidelines for National Greenhouse Gas Inventories: Wetlands, Hiraishi, 
T., Krug, T., Tanabe, K., Srivastava, N., Baasansuren, J., Fukuda, M. and Troxler, T.G. (eds). Published: IPCC, Switzerland. Wetlands_Supplement_Entire_Report.pdf

[23] Jones, T., H. Ratsimba, L. Ravaoarinorotsihoarana, L. Glass, L. Benson, M. Teoh, A. Carro, G. Cripps, C. Giri, S. Gandhi, Z. Andriamahenina, R. Rakotomanana and P.F. Roy. 2015. The dynamics, ecological variability and estimated carbon stocks of mangroves in Mahajamba bay, Madagascar. Journal of Marine Science and Engineering, Vol 3(3): 793-820.

[24] Kauffman J.B., C. Heider, T. Cole, K.A. Dwire, D.C. Donato. 2011. Ecosystem Carbon Stocks of Micronesian mangrove forests. Wetlands 31: $343-352$.

[25] Komiyama, A., Moriya, H., Prawiroatmodjo, S., Toma, T., Ogino, K., 1988. Forest primary productivity. In: Ogino, K., Chihara, M. (Eds.), Biological System of Mangrove, Ehime University, pp. 97-117.

[26] Krauss KW, Keeland BD, Allen JA, Ewel KC, Johnson DJ. 2007. Effects of season, rainfall, and hydrogeomorphic setting on mangrove tree growth in Micronesia. Biotropica 39: $161-170$.

[27] Kristensen, E., S. Bouillon, T. Dittmar and C. Marchand. 2008. Organic carbon dynamics in mangrove ecosystems: a review. Science Direct. Aquatic Botany 89 (2008) 201 219.

[28] Kusmana, C., S. Sabiham, K. Abe and H. Watanabe. 1992. An estimation of above ground tree biomass of a mangrove forest in East Sumatra, Indonesia. Tropics, Vol. 1(4): 243-257.

[29] Kristensen, E., S. Bouillon, T. Dittmar and C. Marchand. 2008. Organic carbon dynamics in mangrove ecosystems: a review. Science Direct. Aquatic Botany 89 (2008) 201 219.

[30] Li, Q, W. Lu, H. Chen, Y. Luo and G. Lin. 2014. Differential responses of net ecosystem of carbon dioxide to light and temperature between spring and neap tides in sub-tropical mangrove forests. Scientific World Journal.

[31] Macreadi, P.I., D.A. Nielsen, J.J. Kelleway, T.B. Atwood, J.R. Seymour, K, Petrou, R.M. Connlly, A.C.G. Thomson, S.M.T. Tackett and P.J. Ralph. 2017. Can we manage coastal ecosystems to sequester more blue carbon? Front Ecol Environ 15(4): 206-213.

[32] Marchio, D.A., M. Savarese, B. Bovard and W.J. Mitsch. 2016. Carbon sequestration and sedimentation in mangrove swamps by hydrogeomorphic conditions and urbanization in Southwest Florida. Forests 7(6).

[33] Matsui, N., K. Morimune, W. Meepol and J. Chukwamdee. 2012. Ten year evaluation of carbon stock in mangrove plantation reforested from an abandoned shrimp pond. Forest, 3: $431-444$

[34] Mcleod, E., G.L. Chmura, S. Bouilon, R. Salm, M. Bjork, C.M. Duarte, C.E. Lovelock, W.H. Sclesinger and B.R. Silliman. 2011. A blueprint for blue carbon: toward an improved understanding of the role of vegetated coastal habitats in sequestering $\mathrm{CO}_{2}$. Frot Ecol Environ 9(10): 552-560.
[35] Menezes, M., U. Berger and M. Worbes. 2003. Annual growth rings and long-term growth pattern of mangrove tress from the Bragamca peninsula, North Brazil. Wetlands Ecology and Management 11: 233-242.

[36] Murdiyarso, D., Donato, D., Kauffman, J.B., Kurnianto, S., Stidham, M., Kanninen, M., 2009. Carbon storage in mangrove and peatland ecosystems: a preliminray account from plots in Indonesia. Working Paper 48. Center for International Forestry Research.

[37] Murdiyarso, D., Purbopuspito, J., Kauffman, J. B., Warren, M. W., Sasmito, S. D., Donato, D. C. \& Kurnianto, S. 2015. The potential of Indonesian mangrove forests for global climate change mitigation. Nature Climate Change. DOI: 10.1038/NCLIMATE2734.

[38] Patil, V., A. Singh, N. Naik, U. Seema and B. Sawant. 2012. Carbon sequestration in mangrove ecosystems. Journal of Environmental Research and Development, Vol 7 No. 1A.

[39] Rixen, T., Mayer, B., Pohlmann, Baum, T.A., Francisca Wit, F., Hutahaean, A.A., 2017. Land use changes and the coastal carbon cycle. World Blue Carbon Conference. At Jakarta Convention Center, 7-9 September 2017.

[40] Sedjo. Roger; Sohngen. Brent (2012). "Carbon Sequestration in Forests and Soils". Annual Review of Resource Economics. Annual Reviews. 4: 127-144. doi:10.1146/annurev-resource-083110-115941.

[41] Sitoe, A.A., L.J.C. Mandlate and B.S. Guedes. 2014. Biomass and carbon stocks of Sofala bay mangrove forests. Forest, 5: 1967-1981.

[42] Stringer, C.E., C.C. Trettin, S.J. Zarnoch and W. Tang. 2015. Carbon stocks of mangroves within the Zamberi river delta $<$ Mozambique. Forest Ecology and Management, Vol 354: 139-148.

[43] Suprayogi, B., Hamy, S., Suriani, M., Rahayu, S. and Suharto, B. 2010. Preliminary Research: Carbon, Community and Biodiversity (CCB) Study. Medan-Indonesia.

[44] Suratman, S. N. 2014. Carbon Sequestration Potential of Mangroves in Southeast Asia. Managing Forest Ecosystems: The Challenge of Climate Change. pp 297-315.

[45] Tamai, S. S., Nakasuga, T., Tabuchi, R., Ogino, K., 1986. Standing biomass of mangrove forests in Southern Thailand. J. Forest Soc. 68: 384-388.

[46] Twilley, R.R., Chen, R.H., Hargis, T., 1992. Carbon sinks in mangroves and their implications to carbon budget of tropical coastal ecosystems. Water, Air, and Soil Polluion, 64: 265-288.

[47] Yang, J., Gao, J., Liu B., Zhang, W. 2014. Sediment deposits and organic carbon sequestration along mangrove coasts of the Leizhou peninsula, Southern China. Estuarine, Coastal and Shelf Science. 136: 2-10.

[48] Zimmermann, A.R. and E.A. Canuel. 2000. A geochemical record of eutrophicatian and anoxia in Chesapeake Bay sediments: Anthropogenic influence on organic matter composition. Mar. Chem 69(1-2): 117-137. 